\title{
Taxonomy of trace fossils from the shallow marine Lower Jurassic Neill Klinter Formation, East Greenland
}

\author{
GREGERS DAM
}

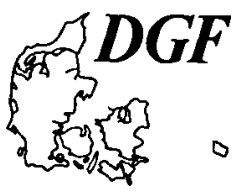

Dam, G.: Taxonomy of trace fossils from the shallow marine Lower Jurassic Neill Klinter Formation, East Greenland. Bull. geol. Soc. Denmark, Vol. 38, pp. 119-144, Copenhagen, april 25th, 1990. https://doi.org/10.37570/bgsd-1990-38-12

\begin{abstract}
Trace fossils are common in the shallow marine sandstones of the Lower Jurassic Neill Klinter Formation, East Greenland. Thirtyfour ichnospecies (4 new) are referred to 29 ichnogenera ( 1 new). The new forms are Jamesonichnites heinbergi (n. igen., n. isp.); Parahaentzschelinia surlyki (n.isp.), Ph ycodes Auduni (n. isp.) and Phycodes bromleyi (n. isp.). Where possible each ichnogenus is interpreted in the light of its trophic and ethological properties and related to a particular group of organisms.
\end{abstract}

Gregers Dam, Geological Survey of Greenland, Østervoldgade 10, DK-1350 Copenhagen K, Denmark, December 28th, 1989.

\section{Introduction}

The Neill Klinter trace fossils constitute the most diverse assemblage present in the Jurassic and Lower Cretaceous marine sandstones of East Greenland. It includes all ichnotaxa, or nearly so, previously documented from the sandstones of the Middle Jurassic Vardekløft Formation of Jameson Land (Heinberg \& Birkelund 1984), the Middle to Upper Jurassic Vardekløft and Bernbjerg Formations of Wollastan Forland, Kuhn $\varnothing$ and Hochstetter Forland (Surlyk \& Clemmensen 1983), and the Middle Jurassic to Lower Cretaceous Charcot Bugt, Kap Leslie and Hartzfjeld Formations of Milne Land (Håkansson, Heinberg \& Willumsen 1971; Heinberg 1973). This paper describes and interpretes the ethology of 34 ichnotaxa and is an ichnotaxonomic supplement to a paper on the palaeo Environmental significance of ichnocoenoses of the Neill Klinter Formation (Dam in press).

\section{Geological setting}

The studied succession belongs to the shallow marine Neill Klinter Formation of Early Pliensbachian to Toarcian age (Rosenkrantz 1929; Surlyk, Callomon, Bromley \& Birkelund 1973; Surlyk, Clemmensen \& Larsen 1981; Sykes 1974b). The formation occurs only on Jameson Land which is situated on the southernmost block of the Mesozoic basin of East Greenland. It marks the first fully marine inundation since the Late Permian transgression. The Neill Klinter Formation overlies the lacustrine, deltaic and braidplain deposits of the Rhaetian-Hettangian/(?)Sinemurian Kap Stewart Formation and is overlain by restricted shelf mudstones of the (?)Upper Toarcian-Aalenian Sortehat Member (Surlyk et al. 1973, 1981; Sykes 1974a; Dam 1989). The Lower Jurassic basin was limited to the north by a crossfault in Kong Oscar Fjord. To the west the basin margin was controlled by a major fault zone and to the east by a SSW-NNE elongated landmass largely corresponding to the present day Liverpool Land (Surlyk et al. 1981). The southern extension is unknown, but the basin may have stretched further south than Scoresby Sund (fig. 1).

The Neill Klinter Formation is exposed in a belt along the eastern and western edges of the basin and across the basin in the northeastern part (fig. 1). The thickness increases from $230 \mathrm{~m}$ in the eastern part of the basin to $320 \mathrm{~m}$ in the central and northern part of the basin. The formation consists of the Rævekløft Member (base), the Gule Horn Member and the Ostreaelv Member (top) (Surlyk et al. 1973). This lithological subdivision reflects the overall depositional environments of the formation (fig. 2).

In the southeastern part of the basin marine 


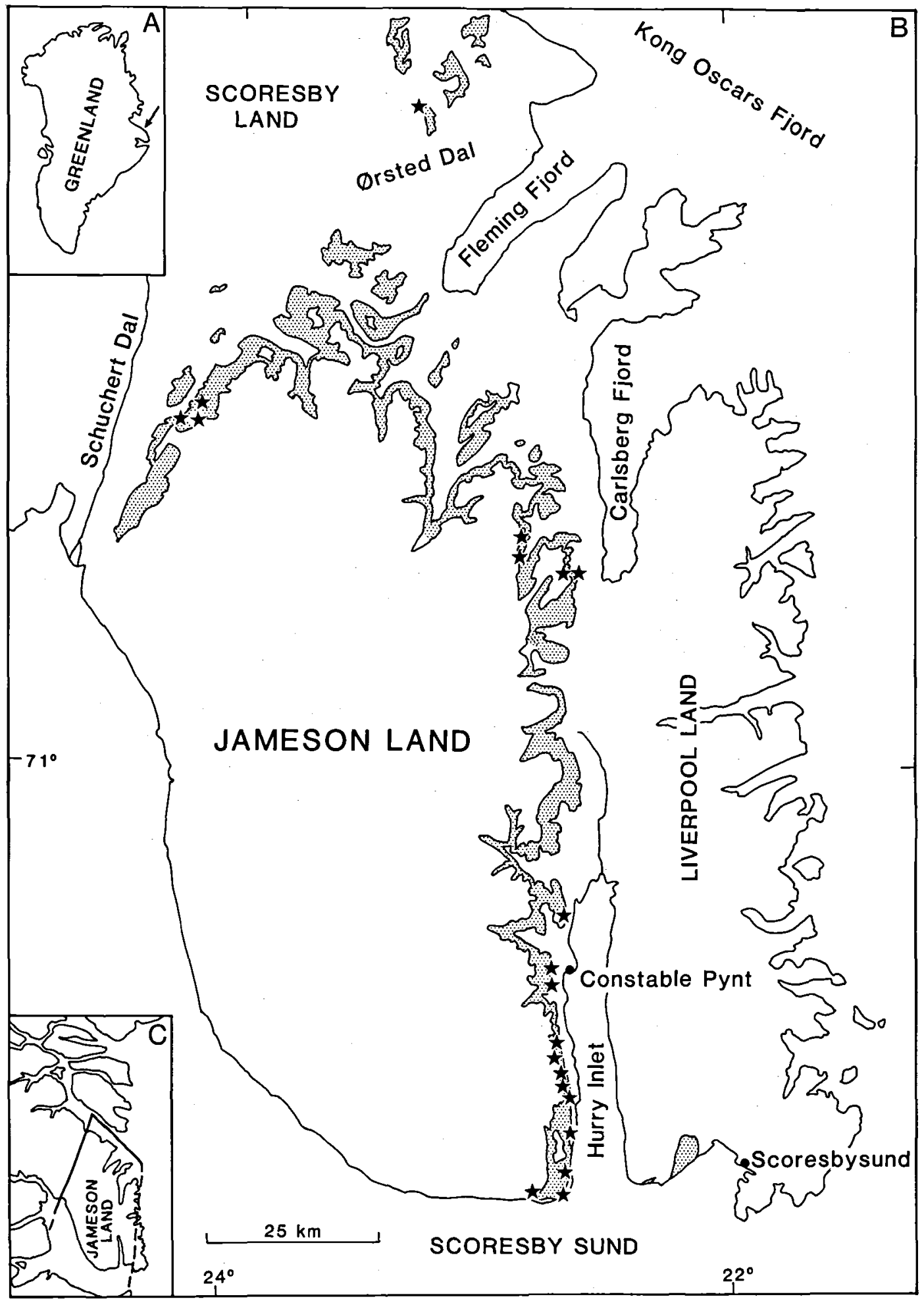


Fig. 1. Outcrops of the Neill Klinter Formation in Jameson Land and Scoresby Land, and location of measured sections (B). Outline of the Jameson Land Basin in Pliensbachian - Toarcian time (C). Based on GGU maps and Surlyk et al. (1973).

deposition was initiated in the Early Pliensbachian by a transgressive pebble lag conglomerate rich in belemnites, present at the base of the Rævekløft Member. Poorly sorted medium to very coarse-grained massive-bedded and crossbedded sandstones deposited in a foreshore environment dominate this member. Body fossils are common in the sandstones and include a rich Lower Pliensbachian dominantly European type marine fauna (listed in Rosenkrantz 1934).

The Gule Horn Member is characterized by rippled heterolithic facies interbedded with crossbedded sandstones deposited in a storm and tidally-influenced shallow marine environment. The deposits are arranged in a series of tabular basinwide coarsening-fining upward sequences possibly reflecting phases of relative sea-level changes.

The Ostreaelv Member consists dominantly of wedges (up to $40 \mathrm{~m}$ thick) of well-sorted medium to coarse-grained cross-bedded sandstones interbedded with bioturbated (95-100\%) shelf sandstones. The cross-bedded sandstone wedges are interpreted as representing the subaqueous portion of westward prograding deltas. Body fossils include a rich marine Toarcian fauna listed by Rosenkrantz (1934). The northern part of the basin is dominated by mica-rich very fine-grained amalgamated hummocky cross-stratified shelf sandstones.

\section{Trace fossils}

The Neill Klinter Formation includes an assemblage of diverse and well-preserved trace fossil fauna including 34 ichnotaxa. Each ichnospecies is, where possible, interpreted with respect to a behavioural pattern (ethology) and to a particular group of organisms (fig. 3).

The ichnofossil assemblage reflects a wide variety of behavioural categories including dwelling, resting, feeding, locomotion and grazing. The trace fossils are inferred to be produced by annelids (or other worm-like organisms), ophiuroids, actiniarian sea anemones, gastropods, bivalves, aplacophorian molluscs, holothurians, crustaceans and other arthropods (fig 3).

\section{Systematic ichnology}

Ichnogenus Ancorichnus Heinberg, 1974

Ancorichnus ancorichnus Heinberg, 1974

(figs 4, 7A)

Description: Cylindrical meniscus filled trace fossil with a structureless tube-shaped mantle, preserved in full relief, hyporelief or epirelief; mantle is separated from the host rock and central tunnel by a thin micacous mud lining; width of burrow is approximately $15 \mathrm{~mm}$, and thickness of the mantle varies between $2-3 \mathrm{~mm}$; course of burrow is slightly undulating, subparallel to the bedding plane; closely associated with Jamesonichnites heinbergi.

Discussion: Ancarichnus ancorichnus has earlier been recorded from the Middle and Upper Jurassic of East Greenland (Heinberg 1974; Fürsich \& Heinberg 1983; Heinberg \& Birkelund 1984). Heinberg (1974) related the burrow to movement of an infaunal soft-bodied organism. The close association with Jamesonichnites heinbergi (see later) suggests that the two burrows represent two different patterns of behaviour of the same organism. Jamesonichnites heinbergi is interpreted as a burrow made by an infaunal depositfeeder systematically mining the sediment for food (fodinichnion), while Ancorichnus ancorichnus comprise the axial domichnion from which the fodinichnial probes of $J$. heinbergi were constructed. A. ancorichnus may also solely be the result of locomotion (repichnion).

\section{Ichnogenus Arenicolites Salter 1857}

\section{Arenicolites isp., Type 1 (fig. 5A)}

Description: Vertical to slightly oblique U-tubes preserved in full relief; tubes are sand filled and have mud lined walls with scattered detrital grains, up to $4 \mathrm{~mm}$ thick; burrow diameter of tubes is $2-3 \mathrm{~mm}$ and spacing of limbs $4-9 \mathrm{~cm}$; base of tubes is semi-circular; burrows are always present in large numbers extending $5-9 \mathrm{~cm}$ in depth from specific bedding planes. 


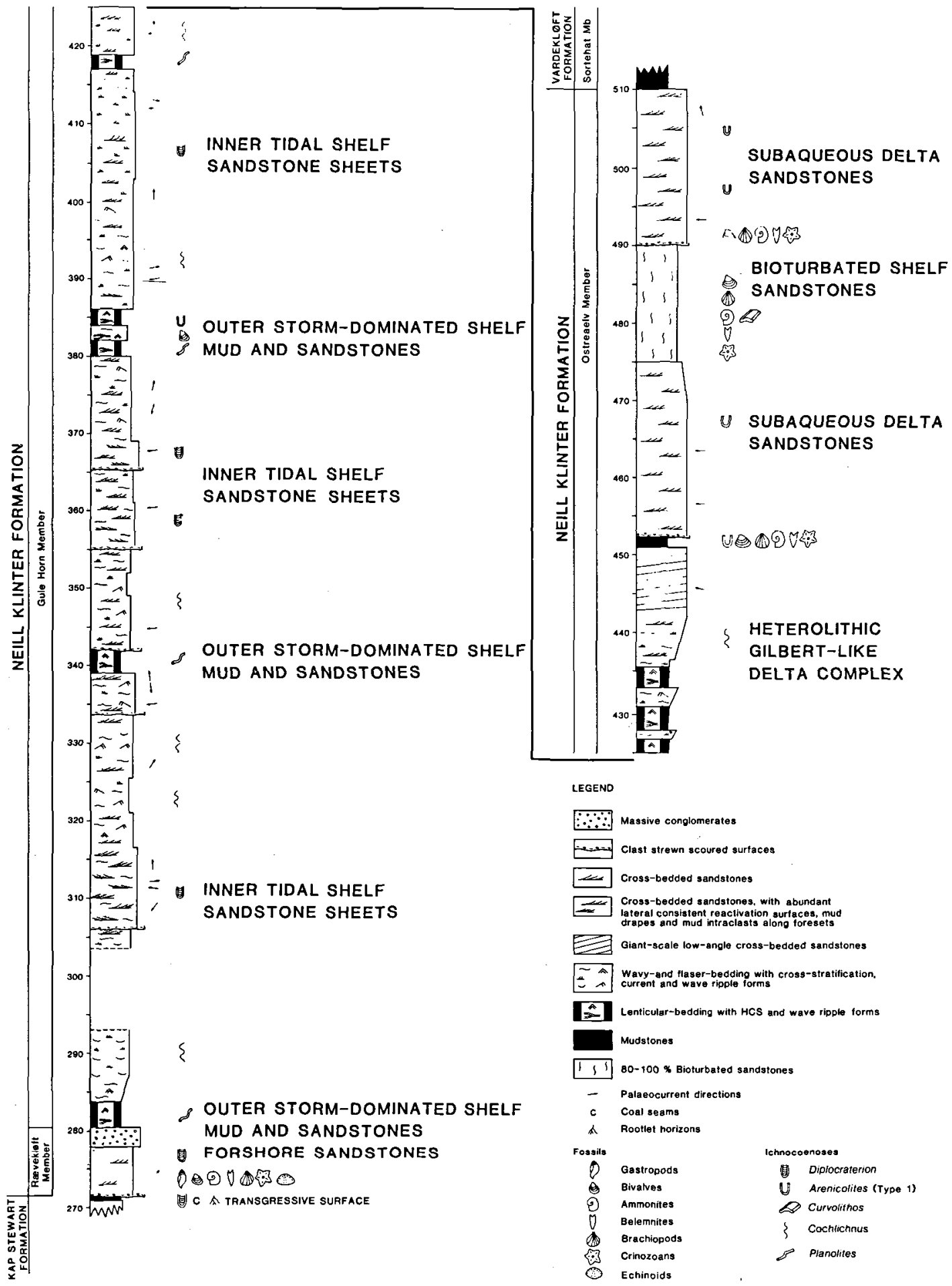

Fig. 2. Summarized columnar section with the position of ichnocoenoses and fossils and interpretation of the Neill Klinter Formation along the eastern margin of the basin (from Dam (in press)). 


\begin{tabular}{|c|c|c|c|}
\hline ICHNOSPECIES & $\begin{array}{l}\text { ETHOLOGICAL } \\
\text { CLASSIFICATION }\end{array}$ & PROBABLE ORIGINATOR & $\begin{array}{l}\text { TROPHIC } \\
\text { CLASSIFICATION }\end{array}$ \\
\hline Ancorichnus ancorichnus & Domichnia/Repichnia & $?$ & Deposit-feeder \\
\hline Arenicolites sp., Type 1 & Domichnia & Annelid (or other worm-like organism) & Suspension-feeder \\
\hline Arenicolites sp., Type 2 & Domichnia & Annelid (or other worm-like organism) & Suspension-feeder \\
\hline Arenicolites sp., Type 3 & Domichnia & Annelid (or other worm-like organism) & Suspenston-feeder \\
\hline Asteriacites Iumbricalis & Cubichnia & Ophiorid and/or asteroid & Carnivore \\
\hline Bergaueria isp. & Cubichnia & Actinarian sea anemone & $?$ \\
\hline Cochlichnus anguineus & Repichnia/Pascichnia & Annelid (or other worm-like organism) & $?$ \\
\hline Cruziana isp. & Repichnia & Arthropod? & Carnivore \\
\hline Curvolithos multiplex & Repichnia & Gastropod & Carnivore \\
\hline Diplocraterion habicki. & Domichnia & Annelid (or other worm-1ike organism) & Suspension-feeder \\
\hline Diplocraterion parallelum & Domichnia & Annelid (or other worm-like organism) & Suspension-feeder \\
\hline Gyrochorte comosa & Pascichnia & Aplacophore & Deposit-feeder \\
\hline Gyrophyllites kwassicensis & Fodinichnia & $?$ & Deposit-feeder \\
\hline Helminthopsis isp. & Pascichnia & Annelid (or other worm-1ike organism) & Deposit-feeder \\
\hline Jamesonichnites heinbergi & Fodinichnia & $?$ & Deposit-feeder \\
\hline Monocraterion tentaculatum & Domichnia & $?$ & Suspension-feeder \\
\hline Nereites isp. & Fodinichnia & Annelid (or other worm-1ike organism) & Deposit-feeder \\
\hline Ophiomorpha nodosa & Domichnia & Thalassinid crustacean & $?$ \\
\hline Palaeophycus alternatus & Domichnia & $?$ & Deposit-feeder \\
\hline Palaeophycus isp. & Domichnia & $?$ & $?$ \\
\hline Parahaentzschelinia surlyki & Domichnia/Fugichnia & $?$ & $?$ \\
\hline Pelecypodichnus amagdaloides & Cubichnia & Bivalve & Suspension-feeder \\
\hline Phoebichnus trochoides & Fodinichnia & $?$ & Deposit-feeder \\
\hline Phycodes auduni & Fodinichnia & $?$ & Deposit-feeder \\
\hline Phycodes bromleyi & Fodinichnia & $?$ & Deposit-feeder \\
\hline Phycosiphon isp. & Fodinichnia & $?$ & Deposit-feeder \\
\hline Planolites beverleyensis & Pascichnia & Annelid (or other worm-like organism) & Deposit-feeder \\
\hline Rhizocorallium irregulare & Fodinichnia & Crustacean/annelid & Deposit-feeder \\
\hline Scolicia isp. & Pascichnia & Holothurian/Polychaete & Deposit-feeder \\
\hline Taenidium serpentinun & Pascichnia & $?$ & 7 \\
\hline Teichichnus isp. & $?$ & Anne1id/Arthopod? & Deposit-feeder \\
\hline Thalassinoides isp. & Fodinichnia & $\begin{array}{l}\text { Thalassinid crustacean } \\
\text { (Glyphea rosenkrantzi) }\end{array}$ & Deposit-feeder \\
\hline Trackway, Type 1 & Repichnia & Arthropod & Carnivore \\
\hline Trackway, Type 2 & Repichnia & Decapod (Crab) & Carnivore \\
\hline
\end{tabular}

Fig. 3. Ethological and trophic classification and probable originator of trace fossils from the Neill Klinter Formation, East Greenland.

Arenicolites isp., Type 2 (fig. 5D)

Description: Irregular, vertical U-tubes preserved in full relief; burrows are sand filled and show no lining; diameter of tubes is $5-10 \mathrm{~mm}$ and spacing of limbs $10-13 \mathrm{~cm}$; base of burrow is generally semi-circular; occur solitarily and extend more than $30 \mathrm{~cm}$ in depth.

Arenicolites isp., Type 3 (fig. 5B, C) MGUH 19613

Description: Small irregular vertical to subvertical U-tubes preserved in full relief, as pairs of small pits in concave epireliefs or soles of burrows in convex hyporeliefs; burrows are generally mud filled and no lining is present; small trum- pet-like openings at the top, never exceeding 2 $\mathrm{mm}$ in diameter; burrow diameter is approximately $1 \mathrm{~mm}$, spacing between limbs range between 3-10 $\mathrm{mm}$ and burrows extend down to 4 $\mathrm{cm}$ in the sediment; always present in large numbers descending from specific bedding planes; occur in close association with Cochlichnus anguineus.

Discussion: Ethologically, Arenicolites represents dwelling burrows of suspension-feeders (domichnion) (e.g. Fürsich 1975; Hakes 1977; Howard \& Frey 1984; Pickerill, Fillion \& Harland 1984; Eager, Baines, Collinson, Hardy, Okolo \& Pollard 1985). The uniform morphology, the presence in distinct horizons, and the thick wall lining of Arenicolites isp. (Type 1), suggest that this bur- 


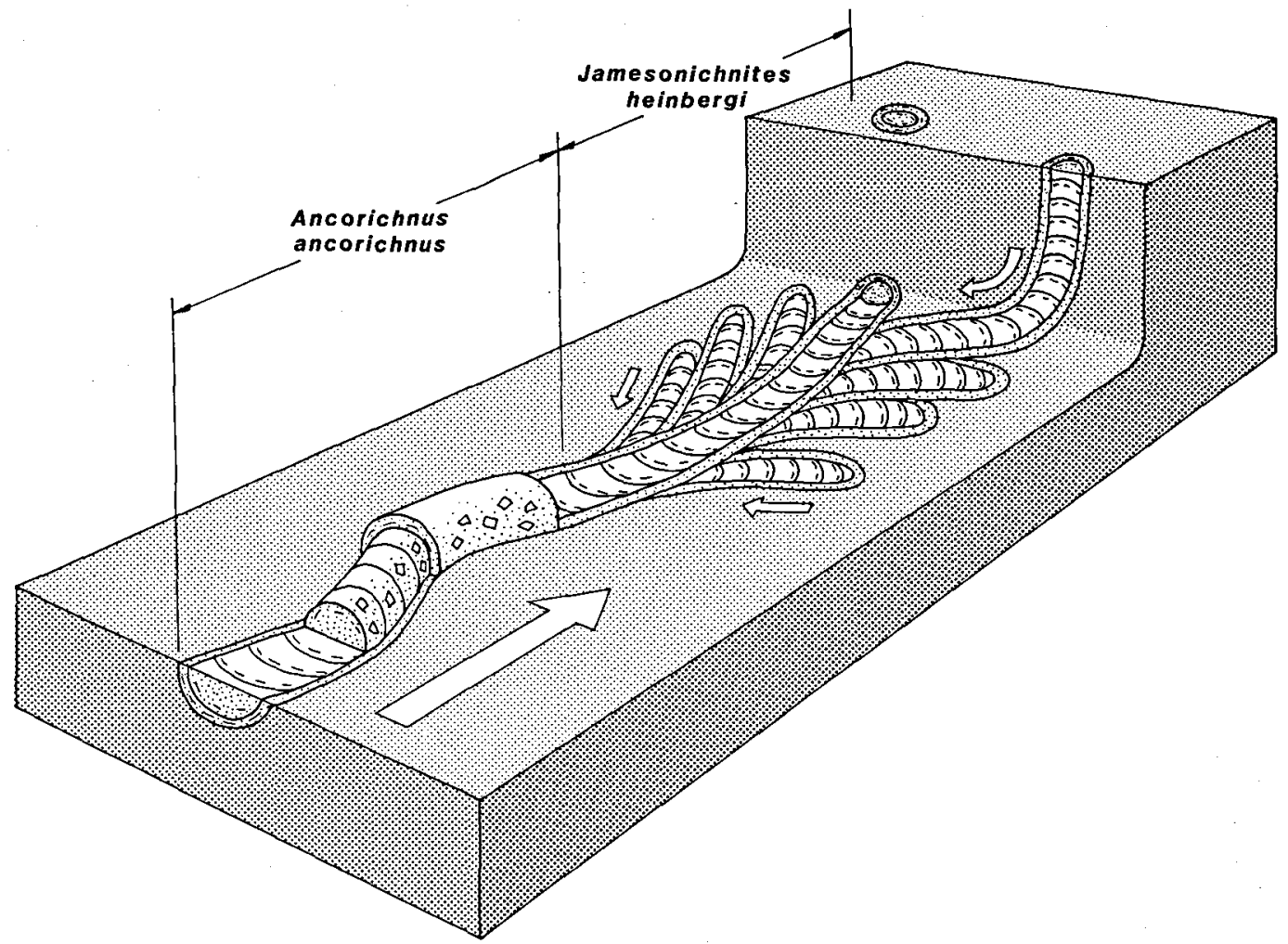

Fig. 4. Model of Ancorichnus and Jantesonichnices showing internal structures and their mutual relationship. Large arrow indicates the principal movement of the organism. The smaller arrows indicate the direction of movement while the organism pulled back after each "mining programme".

row represents a permanent domicile. The morphological variability and irregularity of both Arenicolites isp., Types 2 and 3, and the lack of lining suggest that these burrows only acted as shelters for a short period of time. The co-occurrence of Arenicolites isp., Type 3 and Cochlichnus anguineus suggests that the two traces represent two ethological patterns of the same annelid-like organism.

Ichnogenus Asteriacites von Schlotheim, 1820

Asteriacites lumbricalis Seilacher, 1953 (fig. 5E) MGUH 19614

Description: Starfish-shaped trace, preserved in convex hyporelief; consists of 5 slender 'arms', 12-20 $\mathrm{mm}$ long and 2-3 $\mathrm{mm}$ wide, decreasing distally; central part of the trace is $5-7 \mathrm{~mm}$ in diameter.

Discussion: Asteriacites is generally classified as cubichnia of ophiuroids or asteroids (e.g. Seilacher 1953). The morphology of the present species suggests an ophiuroid origin.

\section{Ichnogenus Bergaueria Prantl, 1945}

\section{Bergaueria isp. (fig. 5G)}

Description: Subhemispherical, vertical burrows possessing smooth, unornamented walls, elliptical in vertical and horizontal cross-sections; rounded or flattened base; occurs individually or in clusters on soles of sandstone beds as convex hyporeliefs; diameters are $2-4 \mathrm{~cm}$ and up to 1.5 $\mathrm{cm}$ deep; sand fillings structureless.

Discussion: Pemberton, Frey \& Bromley (1988) recognized four ichnospecies, $B$. perata, $B$. langi, $b$. radiata and $B$. hemispherica. The Neill Klinter specimens most closely resembles $B$. hemispherica but is more flattened underneath. Bergaueria probably result from the activities of a cnidarian 

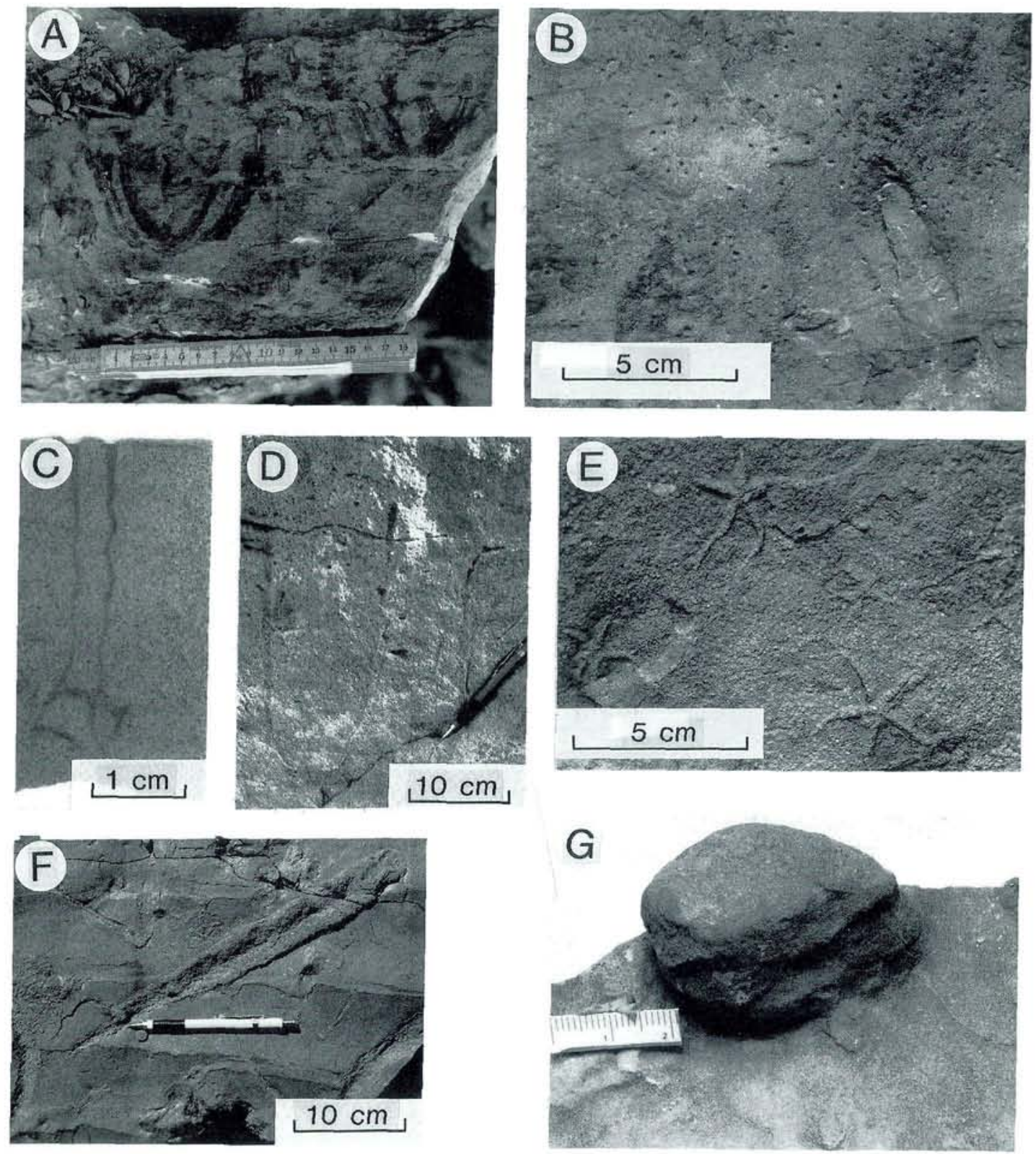

Fig. 5. A. Arenicolites isp.. type 1, full relief, dark shadows around the central sand filled tubes are thick mud lined walls, scale in centimetres; B. Arenicolites isp.. Type 3 (MGUH 19613), pairs of small pits preserved in concave epirelief; C. Arenicolites isp., Type 3, x-radiograph, full relief; D, Arenicolites isp., Type 2, full relief; E, Asteriacites lumbricalis (MGUH 19614), convex epirelief: F Scolicia isp. (MGUH 19631), convex epirelief; G. Bergaueria isp... convex hyporelief, scale in centimetres.

(Alpert 1973). The lack of obvious physal markings suggest that the present Bergaueria species represents a cubichnion rather than actual dwellings (cf. Pemberton et al. 1988).

Ichnogenus Cochlichnus Hitchcock, 1858
Cochlichnus anguineus Hitchcock, 1858 (fig. 6A) MGUH 19615

Description: Sinuous traces preserved as concave epireliefs in part with marginal ridges; curves are very uniform and show a high sinuosity; trace diameter $1 \mathrm{~mm}$; generally less than $5 \mathrm{~cm}$ long; 

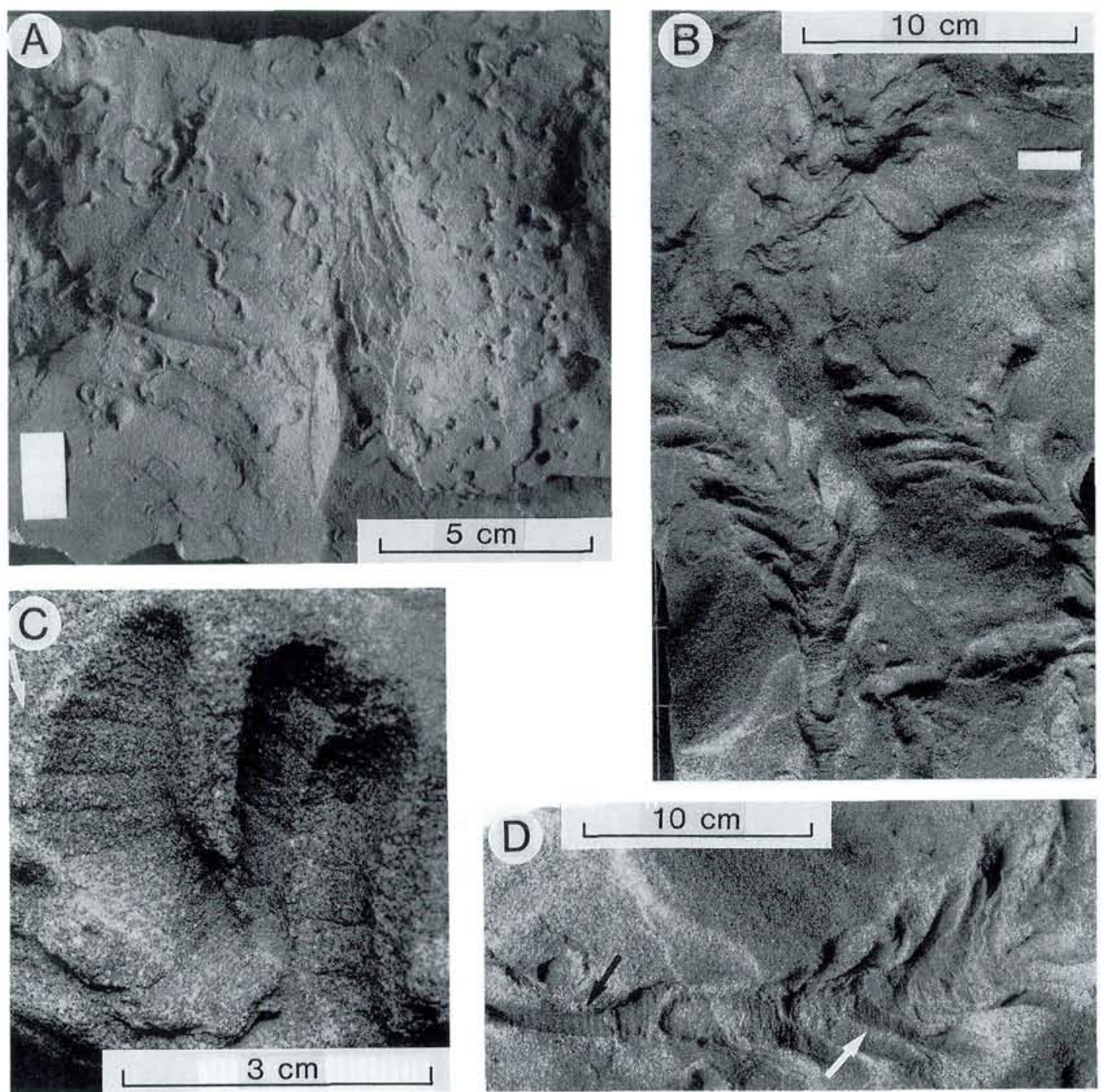

Fig. 6. A, cochlichnus anguineus (MGUH 19615) and Arenicolites isp., Type 3, concave epirelief; B, Jamesonichnites heinbergi (MGUH 19621), notice the central meniscus-shaped fill is weathered out; C, Chevronichnus heinbergi (MGUH 19621), concave epirelief, transverse furrows marked on the inside of mantle from the central meniscus-shaped fill. Mantle is separated from the surrounding sediment by a thin mud film (white arrow); D, Relation between Ancorichnus ancorichnus (black arrow) and Jamesonichnites heinbergi (white arrow), concave epireliefs.

amplitude of curves less than $5 \mathrm{~mm}$; wavelength 10-15 mm; spatially associated with Arenicolites isp. (Type 3).

Discussion: Cochlichnus is regarded as either a grazing trail (pascichnion) or, more likely, a locomotion trail (repichnion) of a worm-like organism. The co-occurrence with Arenicolites isp. (Type 3) suggests that the two traces were produced by similar worms showing two different patterns of behaviour. The trace-maker of
Cochlichnus is generally regarded as a wormlikeorganism (e.g. Webby 1970; Eager et al. 1985). Modern sinusoidal trail, similar to Cochlichnus, was made by a biting midge (family Ceratopogonidae, genus? Bezzia) (Metz 1987) and nematodes (e.g. Moussa 1970).

Ichnogenus Cruziana d'Orbigny, 1842

Cruziana isp. (fig. 8B)

MGUH 19616 

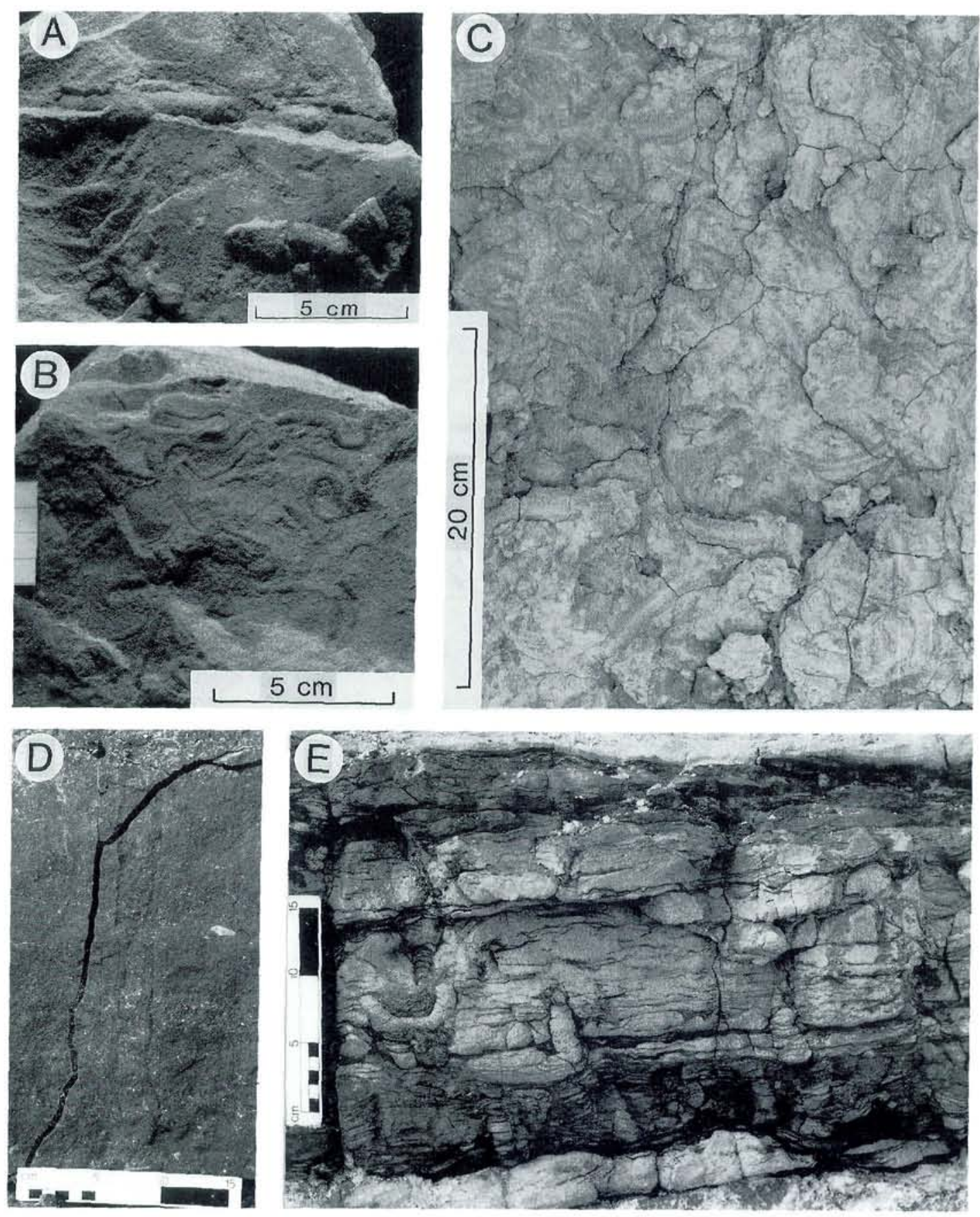

Fig. 7. A. Ancorichnus ancorichnus, full relief: B. Helminthopsis magna (MGUH 19620), convex epirelief; C. Curvolithos multiplex. heavily bioturbated, epirelief: D, E. Diplocraterion parallelum, full relief.

Description: Elongate, bilobed furrows preserved in convex hyporelief; furrows are 10-20 $\mathrm{mm}$ in width; the burrow fill shows bilobate backfill structures which on the under surface are present as transverse ridges arranged in a chevron-like pattern.

Discussion: Ethologically, Cruziana is generally 

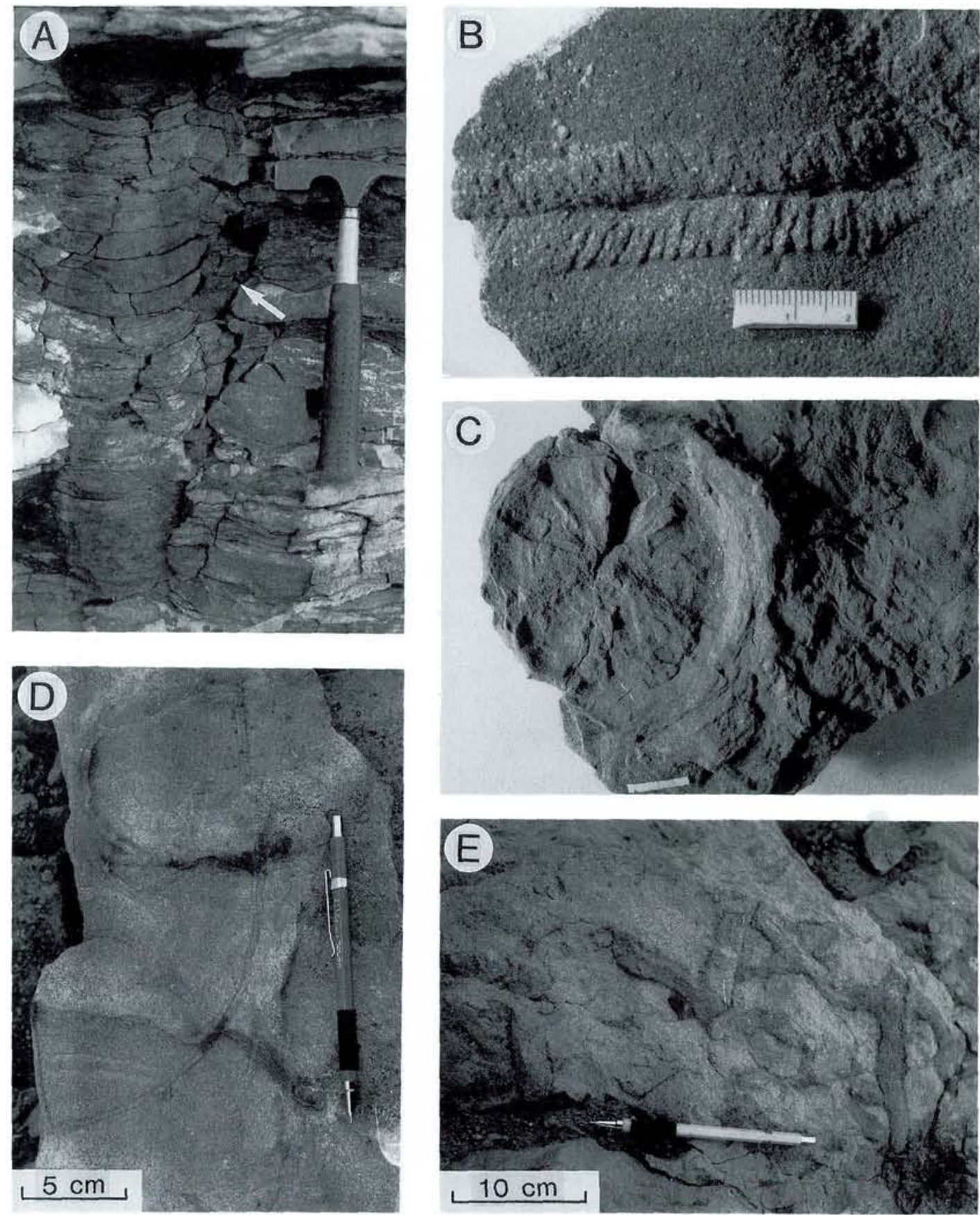

Fig. 8. A. Diplocraterion parallelum, full relief, protrusive spreite occurs above and retrusive spreite below the last tunnel occupied by the burrower (arrow), hammer for scale (28 cm long); B, Cruziana isp. (MGUH 19616), convex hyporelief, scale in centimetres; C, Gyrophyllites kwassicensis (MGUH 19617), concave epirelief: D, Gyrochorte comosa, convex epirelief; E. Ophiomorpha nodosa. convex epirelief.

regarded as repichnia produced by arthropods (e.g. Seilacher 1955, 1977; Bromley \& Asgaard 1979). Gastropods, polychaetes, branchiopods and trilobites are considered as possible trace makers of the very similar Rusophycus, the cubichnial equivalent of Cruziana (Seilacher 1960). 
This large variety of possible trace makers preclude the possibility of saying anything about the biological affinities of the Neill Klinter specimens.

\section{Ichnogenus Curvolithos Fritsch, 1908}

Curvolithos multiplex Fritsch, 1908 (fig. 7C)

Description: Straight to slightly curved subhorizontal burrows with a positive trilobate epirelief and a positive bilobate hyporelief; trilobate epirelief consists of a broad median ridge and two narrower lateral ridges, similar to type 1 of Heinberg (1970); hyporelief is generally poorly preserved and consists of two narrow ridges separated by a broad flat groove; $14-23 \mathrm{~mm}$ in width and $3-6 \mathrm{~mm}$ in thickness.

Discussion: $C$. multiplex has been recorded from several stratigraphic intervals throughout the Middle and Upper Jurassic shelf deposits of East Greenland (Heinberg 1970, 1973; Fürsich \& Heinberg 1983; Heinberg \& Birkelund 1984; Surlyk \& Clemmensen, 1983) and is carefully described and interpreted by Heinberg (1973). Heinberg (1973) attributed the trace to the activity of a carnivorous gastropod. Based on this interpretation the trail is classified as a repichnion (Heinberg \& Birkelund 1984).

Ichnogenus Diplocraterion Torell, 1870

\section{Diplocraterion habicki Lisson, 1904}

Description: Long, slender vertical U-burrows preserved in full relief; depth of burrows is 50$100 \mathrm{~cm}$; tube diameter approximately $4 \mathrm{~mm}$; distance between limbs 5-10 $\mathrm{mm}$; sand filled.

Interpretation: $D$. habichi is known from several stratigraphic levels of the Jurassic and Lower Cretaceous of East Greenland (Heinberg \& Birkelund 1984; Surlyk \& Noe-Nygaard 1989). The present species are very poorly preserved and is only tentatively assigned to $D$. habichi as the spreite structures, described by heinberg \& Birkelund (1984), were not recognizeable. Possibly, the burrow should be referred to as Arenicolites.

The burrow was made for shelter by a suspension-feeding organism and is classified as a domichnion (Heinberg \& Birkelund 1984).
Diplocraterion parallelum Torell, 1870

(figs $7 \mathrm{D}, \mathrm{E}, 8 \mathrm{~A}$ )

Description: Vertical U-shaped burrows preserved in full relief with concave-upward spreiten; spreiten is enhanced by lining of the walls; limbs of burrow walls are parallel. Both retrusive and protrusive forms occur and few specimens display both forms; bottom of burrows are semicircular or more rarely flattened; burrows are 8-25 $\mathrm{mm}$ in tube diameter and $25-180 \mathrm{~mm}$ in distance between limbs; depth of burrows is 25$510 \mathrm{~mm}$; smaller specimens occur in large numbers in distinct horizons, while larger specimens mostly occur solitarily.

Discussion: Diplocraterion is generally interpreted as a dwelling burrow (domichnia) of suspension-feeding organisms (e.g. Mason \& Christie 1986). Evidence of retrusive and protusive spreiten probably reflect the burrowing organism's reaction to environmental factors, such as erosion or deposition (Fürsich 1974b; Mason \& Christie 1986). The Neill Klinter Formation $D$. parallelum reach greater widths than have previously been reported. Häntzschel (1975) compiled examples from 10 to $70 \mathrm{~mm}$ wide.

Ichnogenus Gyrochorte Heer, 1865

Gyrochorte comosa Heer, 1865 (fig. 8D)

Description: Epireliefs comprising two ridges and a medium groove or as hyporeliefs as two grooves separated by a median ridge; seldom preserved in full relief with double ridge structures continuously repeated down through the sediment connecting the epirelief and hyporelief; burrow often strongly winding, intersecting itself; $2-9 \mathrm{~mm}$ in width maximum vertical extent observed is 27 $\mathrm{mm}$; epireliefs often show bakfill structures which are biserially arranged as obliquely aligned pads of sediment, hyporelief grooves may reveal corresponding imprints of the pads.

Discussion: $G$. comosa has been recorded in several stratigraphic levels of the Middle and Upper Jurassic shelf deposits of East Greenland (Heinberg 1973; Fürsich \& Heinberg 1983; Surlyk \& Clemmensen 1983; Heinberg \& Birkelund 1984) and was carefully described and discussed by 
Heinberg (1973). It is interpreted as a pascichnia and is attributed to the deposit-feeding activity of an aplacophoran mollusc, moving through the sediment (Heinberg \& Birkelund 1984).

\section{Ichnogenus Gyrophyllites Glocker, 1841}

\section{Gyrophyllites kwassicensis Glocker, 1841}

(figs 8C, 12A, B)

MGUH 19617, MGUH 19618, MGUH 19619

Description: Vertical or oblique shaft from which 10 to several tens of straight, closely spaced tunnels radiate in whorled or stacked arrangement; rosettes up to $9 \mathrm{~cm}$ in diameter preserved in epirelief or full relief; central shaft has an incomplete depth of $5 \mathrm{~cm}$, possibly only representing a small part of its original extent; shaft diameter is $10-14 \mathrm{~mm}$ and internally the mica grains show a preferred orientation parallel to the wall; from the shaft the radial burrows emerge very closely in a constricted interval, less than 4 $\mathrm{cm}$ thick, often cutting one another; tunnels are 6-15 mm in width, may expand distally and comprise an active fill; tunnels are lined with micaceous muds; mica-flakes stand more of less parallel to the burrow axis; in the distal end the lining closes the tunnel; fill is normally structureless, but in a few cases in which meniscus structures are distinguished, concave towards the central tube.

Discussion: The central shaft of stellate trace fossils is generally regarded as the burrow where the trace-maker lived (e.g. Häntzschel 1970; Bromley \& Asgaard 1972). From this central shaft the radial tunnels were constructed and refilled, probably in search for food. During the outward journey the lining was probably produced, whereas the preserved meniscus, concave towards the central shaft, suggests that the structures of the active fill were produced on the return jurney to the shaft. The burrow is designated as a fodinichnion.

Ichnogenus Helminthopsis Heer, 1877

Helminthopsis magna Ulrich, 1904 (fig. 7B)

\section{MGUH 19620}

Description: Simple smooth free-meandering trails, 1-2 $\mathrm{mm}$ in width, preserved in full reliefs or as concave epireliefs on top of highly bioturbated rippled bedding planes; meanders are very irregular and never branch; burrow fill is darker than the host rock, probably owing to higher organic/mud content; each trail can only be followed for a maximum of a few centimetres.

Discussion: Helminthopsis is considered to be a pasichnion trace formed within the substrate by a deposit-feeding worm-like organism.

Ichnogenus Jamesonichnites n. igen.

Etymology: Named after Jameson Land.

Diagnosis: As for ichnospecies.

Jamesonichnites heinbergi $\mathbf{n}$. isp.

(figs. 4, 6B, C, D)

MGUH 19621

Holotype: The specimen illustrated in figs $6 \mathrm{~B}, \mathrm{C}$, D (MGUH 19621), is designated as the holotype. the figured material was collected in the Gule Horn Member, Neill Klinter Formation. Cliff section on Harris Fjeld (approx. $310 \mathrm{~m}$ above sea-level), north of Constable Pynt; $70^{\circ} 01^{\prime} \mathrm{N}$, $22^{\circ} 42^{\prime} \mathrm{W}$.

Etymology: Named after Claus Heinberg, a veteran in the study of Jurassic trace fossils from East Greenland.

Diagnosis: Cylindrical meniscus filled tunnels with a distinct mantle, arranged in a subhorizontal chevron-shaped burrow system.

Description: cylindrical tunnels arranged in a subhorizontal chevron-shaped burrow system, generally preserved in concave epirelief; length of burrow system is $6-15 \mathrm{~cm}$ and is up to $7 \mathrm{~cm}$ in width. The cylindrical tunnels are meniscus filled and have a structureless mantle that is separated from the surrounding sediment and central fill by thin micaceous mud linings; width of tunnels is 10-20 $\mathrm{mm}$ and the thickness of the mantle varies between $2-3 \mathrm{~mm}$; central fill is often weathered out and only marked as well-preserved transverse furrows, less than $1 \mathrm{~mm}$ across, on the inside of the mantle; spacing of furrows is $2-5 \mathrm{~mm}$. The 


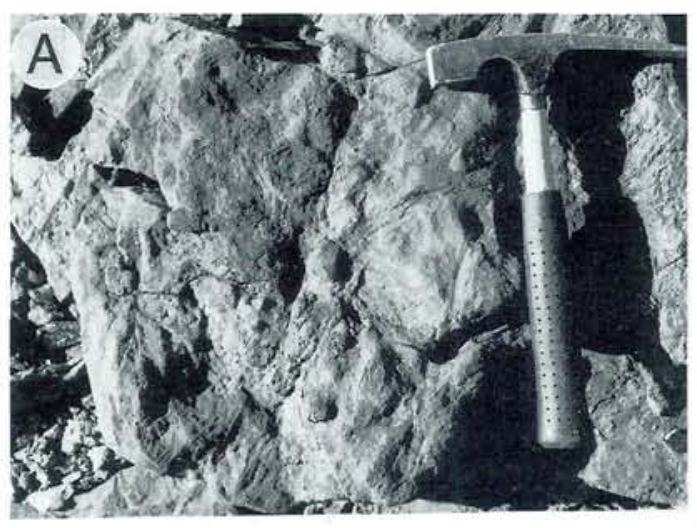

C

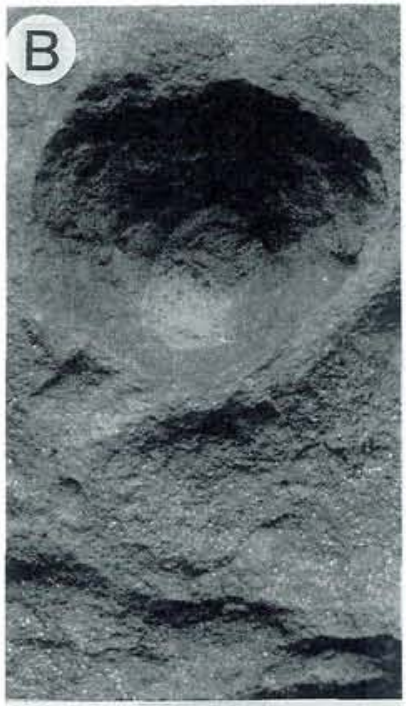

$10 \mathrm{~cm}$
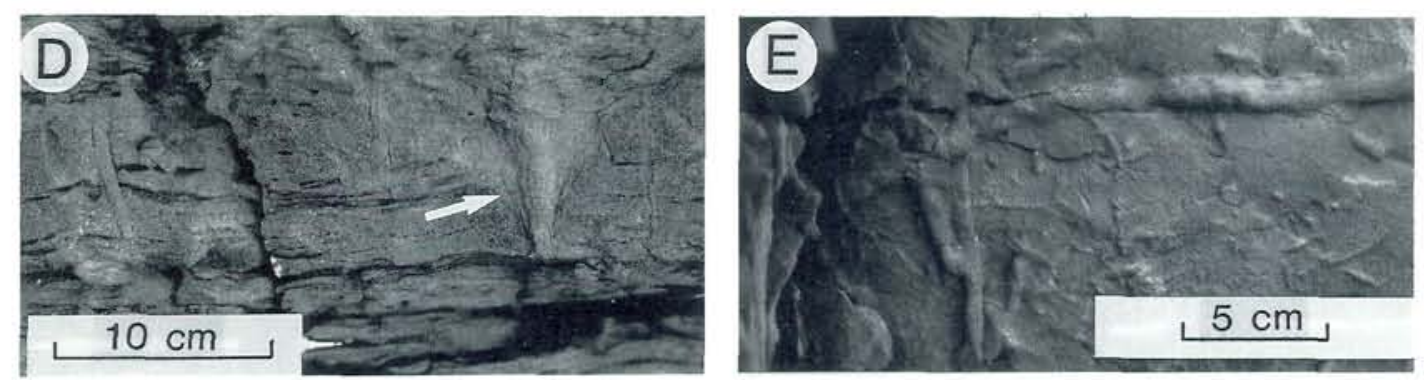

Fig. 9. A, Phoebichnus trochoides, epirelief, hammer for scale (28 cm long); B, Monocraterion tentaculatum (MGUH 19622), concave epirelief; C) Pelecypodichnus amygdaloides (MGUH 19623), convex hyporelief; D, Monocraterion tentaculatum (arrow), full relief: E. Planolites beverleyensis, convex hyporelief.

tunnels divide alternately from each side of the midline of the burrow system, giving rise to the chevron-shaped pattern; distally, the tunnels become vertical or nearly vertical and extend up to
$5 \mathrm{~cm}$ in height (fig. 4). The burrow system is present in medium-grained cross-laminated sandstone beds, closely associated with ancorichnus ancorichnus. 

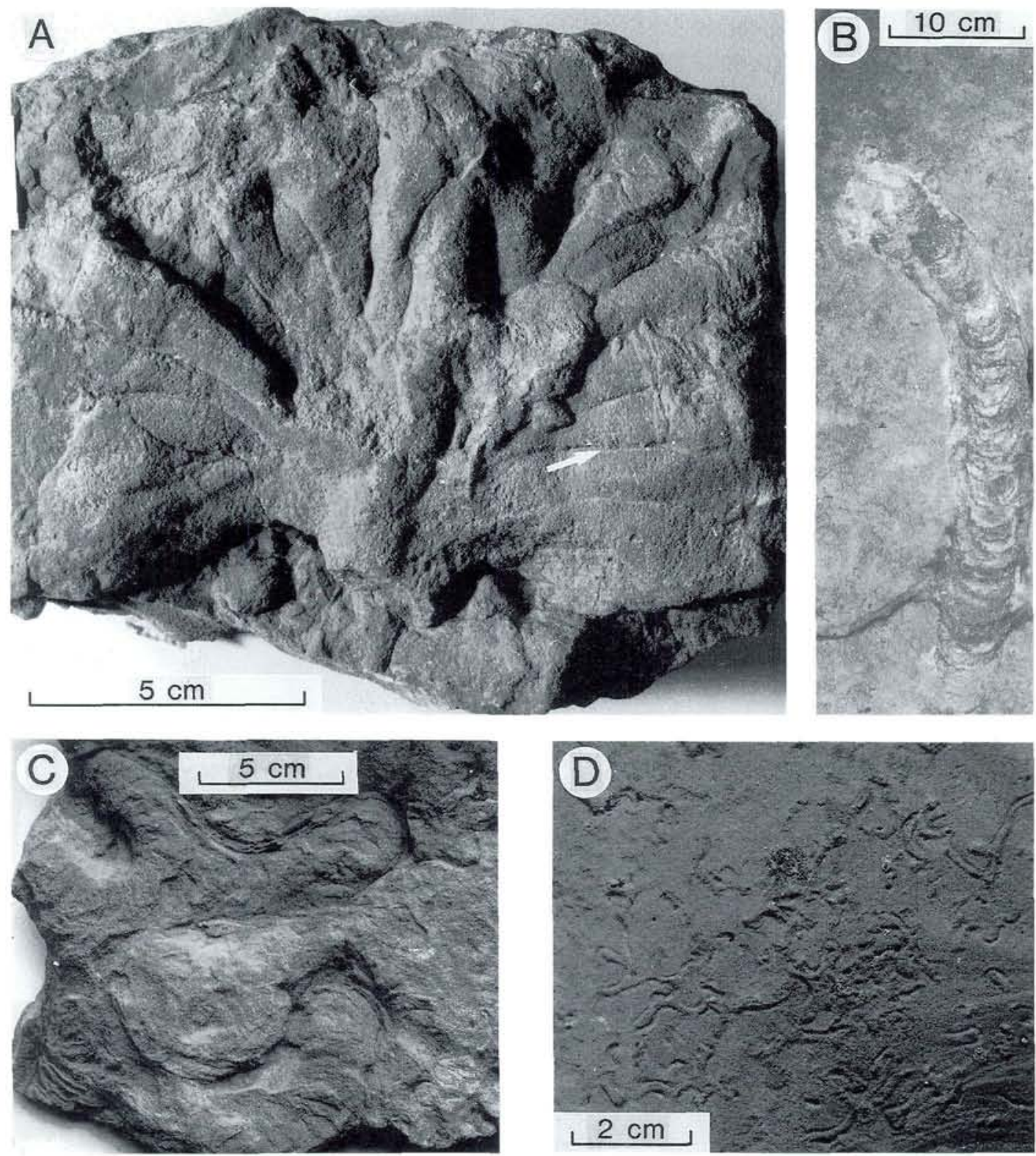

Fig. 10. A, Phycodes Bromleyi (MGUH 19627), convex hyporelief, faint annulations of the tunnels are marked by arrow; B. Rhizocorallium irregulare; C, Rhizocorallium irregulare (MGUH 19630), epirelief; D. Phycosiphon incertum (MGUH 19629). epirelief.

Discussion: The internal organization of the meniscus filled tunnels is the same as in Ancorichnus ancorichnus, described by Heinberg (1974), but the present burrow clearly differs in its branching chevron-shaped organization which forms the basis for the erection of a new ichnogenus. The present form differs from Rutichnus rutis, described by D'Alessandro, Bromley \& Stemmerik
(1987), by having smoother outer walls and a much more regular branching. Heinberg (1974) showed that both the tube-shaped mantle and the central meniscus filled tunnel of Anchorichnus anchorichnus could be constructed simultaneously by a softbodied organism using 'anchors', moving in one direction through the sediment. Essentical differences from Heinberg's (1974) 

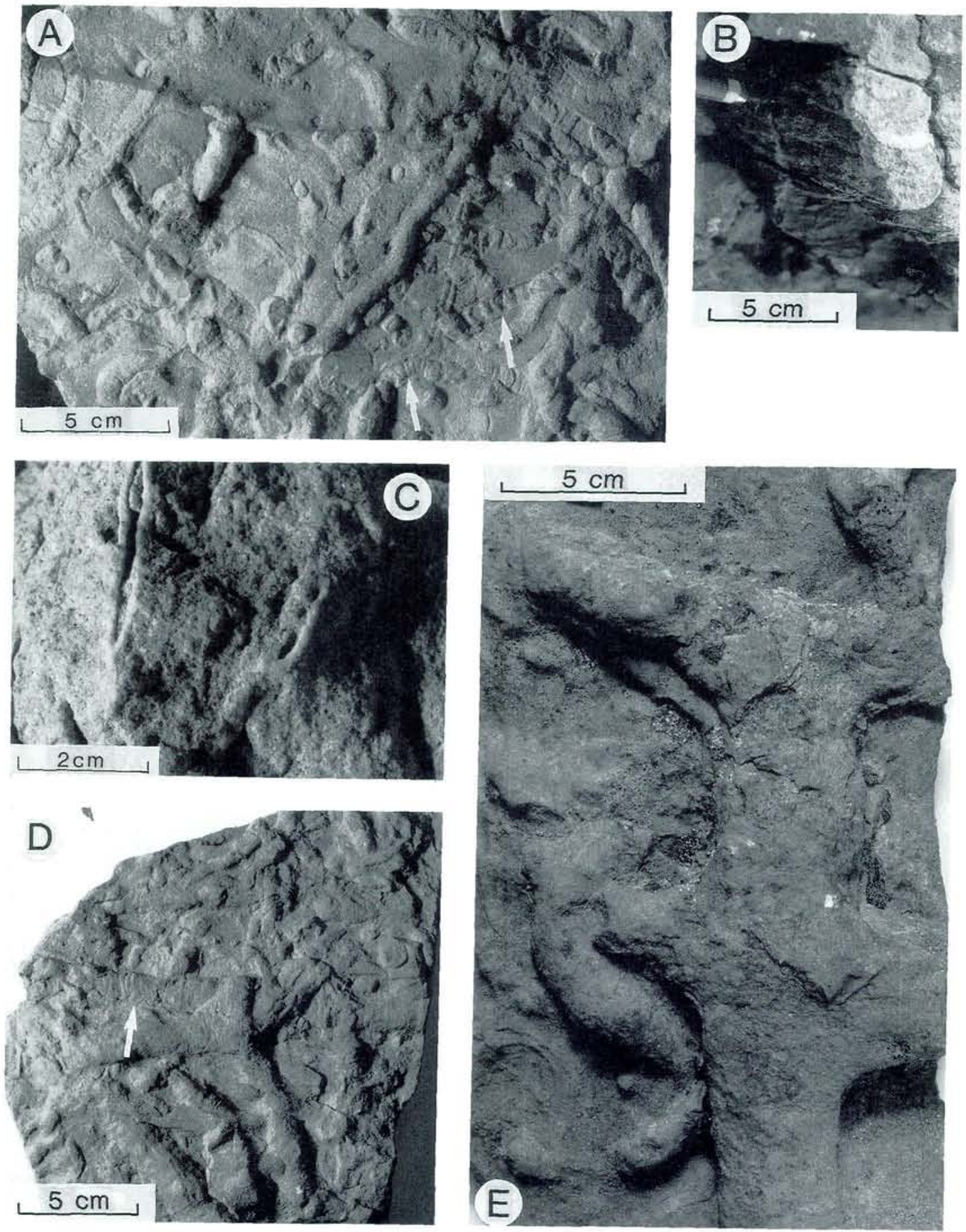

Fig. 11. A. Taenidium serpentinum (MGUH 19631), epirelief, notice arcuate backfill structures (arrow); B. Teichichnus isp.. full relief: C. Reworked Palaeophycus isp. (MGUH 19624). full relief; D, Palaeophycus alternatus (arrow) (MGUH 19623). convex hyporelief: notice annuli expressed on the outer surface of the burrow as concentric rings; E. Thalassinoides isp. (MGUH 19633). convex hyporelief. 
Ancorichnus model are the double jurney necessitated by the branching nature of Jamesonichnites. The present burrow was probably produced in the same way by the same organism, but reflecting a different behaviour. The systematic pattern of the burrow system and the closed tunnels suggests that the organism made a double journey, first mining forward and upward and then backwards using the same tunnel, in the same way as D'Alessandro et al's (1987) Rutichnus model. Then advancing in a trajectory laterally reversed to the first, pulling backwards, then moving a little forward and so on, suggesting an overall movement parallel to the direction of the opening of the chevrons (fig. 4). The preserved meniscus filled tunnel and the wall structure probably formed on the return journey of each mining event. There is no information to suggest whether the whole organism undertook this journey, or only part of it. This systematic pattern is related to a deposit-feeding behaviour of an infaunal soft-bodied organism moving through the sediment (fodinichnia).

Ichnogenus Monocraterion Torell, 1870

Monocraterion tentaculatum Torell, 1870

(figs 9B, D)

MGUH 19622

Description: Funnels penetrated by central straight or slightly curved tubes, perpendicular to bedding surfaces; funnels are circular and up to about $5 \mathrm{~cm}$ in diameter and $6.5 \mathrm{~cm}$ deep; tubes are more than $8 \mathrm{~cm}$ long, sand filled and diameter is $3-5 \mathrm{~mm}$; mud lining is present along burrow wall of both tubes and funnels and gives rise to a series of dark concentric rings in transverse sections; tubes with the same dimensions but without funnels are often associated with Monocraterion.

Discussion: the close association between Monocraterion and tubes without funnels (Skolithos) with similar characteristics suggest that Skolithos was produced by eroding away the top of Monocraterion tubes (Goodwin \& Anderson 1974). Monocraterion probably represents the dwelling burrow of a suspension-feeder (domichnion).

Ichnogenus Nereites MacLeay, 1839
Nereites isp.

Desription: Poorly preserved meandering traces preserved as epireliefs; comprisning a narrow median mud-filled furrow, flanked on both sides by spherical to pinnate lobes; where the lobes are closely spaced they commonly have a pinnate form, but with increasing spacing they become more spherical; traces are $7-11 \mathrm{~mm}$ wide with lobes normally no more than $5 \mathrm{~mm}$ long; median furrow is no more than $2 \mathrm{~mm}$ wide.

Discussion: Ethologically, Nereites is regarded as a systematic deposit-feeding behaviour of an infaunal worm-like organism and can be classified as a fodinichnion (Seilacher \& Meischner 1965).

Ichnogenus Ophiomorpha Lundgren, 1891

Ophiomorpha nodosa Lundgren, 1891 (fig. 8E)

Description: Vertical to horizontal branching burrow systems; burrows are cylindrical and possess smooth interior walls and distinct nodose exterior surfaces consisting of dense, regularly distributed pellets, $2-4 \mathrm{~mm}$ in diameter; walls are one-pellet thick and the smooth interior has commonly further a thin dark wall lining; burrows are generally exposed in full relief often showing Yshaped branching; burrows are 3-30 $\mathrm{mm}$ in diameter, and may be constricted at branching points; burrow fill is passive and is composed of sand, identical to the host rock.

Discussion: The pelleted wall lining of $O$. nodosa seems to be related to substrate coherence, which was probably incohesive and loose at the time of burrowing. Ethologically, $O$. nodosa probably represents a dwelling structure. Thalassinidean shrimps construct similar structures today (e.g. Frey, Howard \& Pryor 1978).

Ichnogenus Palaeophycus Hall, 1847

Palaeophycus alternatus Pemberton \& Frey, 1982 (fig. 11D)

MGUH 19623

Description: Long, slightly curved interstratal subhorizontal tubes preserved in full relief or convex epirelief; rarely branching; composed of a 

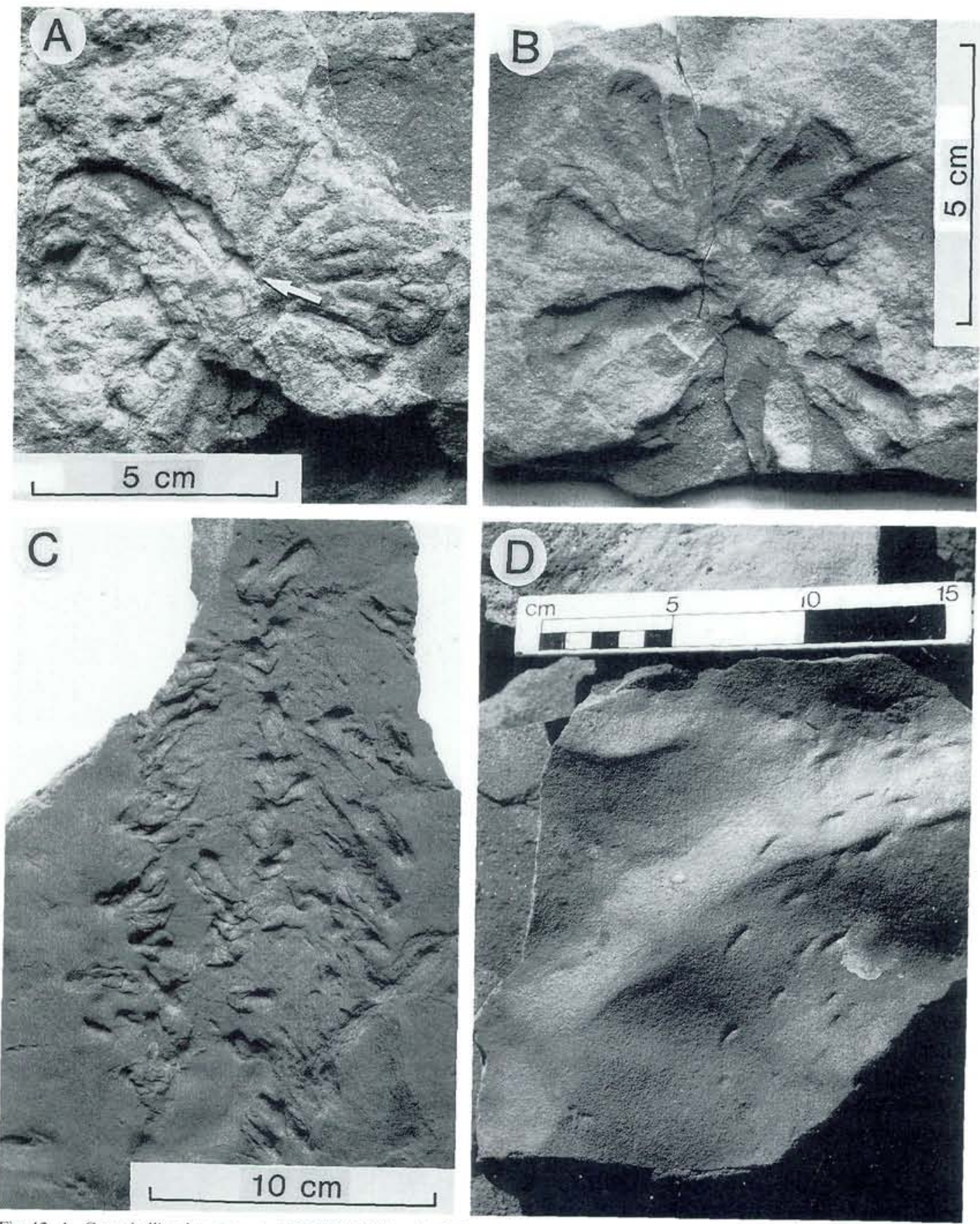

Fig. 12. A, Gyrophyllites kwassicensis (MGUH 19618), epirelief, notice central shaft (arrow); B. Gyrophyllites kwassicensis (MGUH 19619), epirelief: C. Trackway, Type I (MGUH 19634), concave epirelief; D. Trackway, Type 2, concave epirelief.

central lumen, c. $15 \mathrm{~mm}$ wide, containing passive sandy fill, and a sandy lining, c. $5 \mathrm{~mm}$ thick, occasionally composed of discrete annuli imparted on the outer surface of the burrow as concentric rings; a further micaceous mud lining is usually present between the central lumen and the sandy lining structure and the sandy lining and the host rock; tubes may locally show var- 

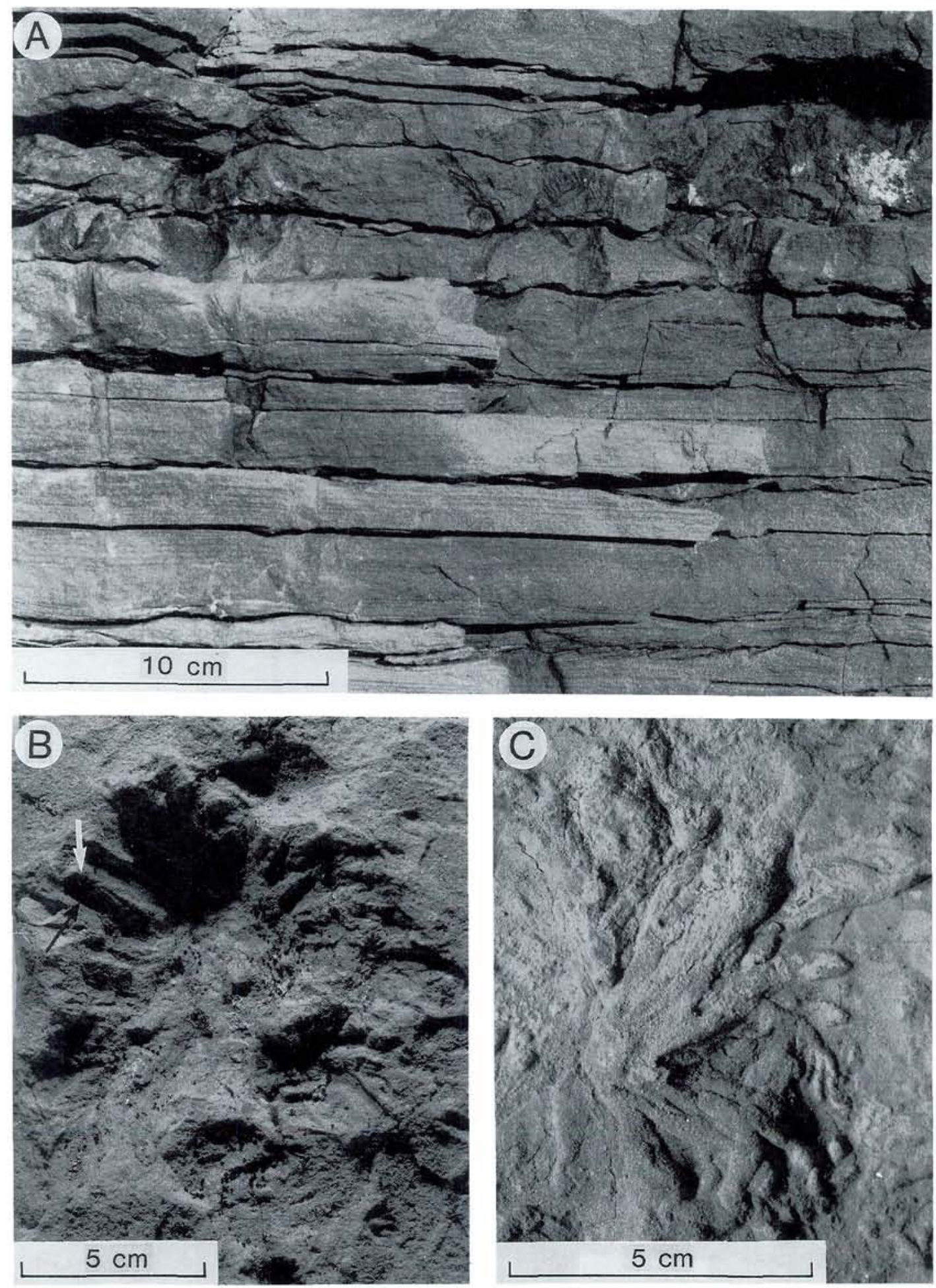

Fig. 13. A. Parahaentzschelinia surlyki present in large numbers within a distinct horizon, full relief; B, Parahaentzschelinia surlyki preserved on a bedding surface as a conical depression (MGUH 19625), epirelief. notice sand filled tunnels (white arrow) with thick mud linings (black arrow); C. Phycodes auduni (MGUH 19628), convex hyporelief. 


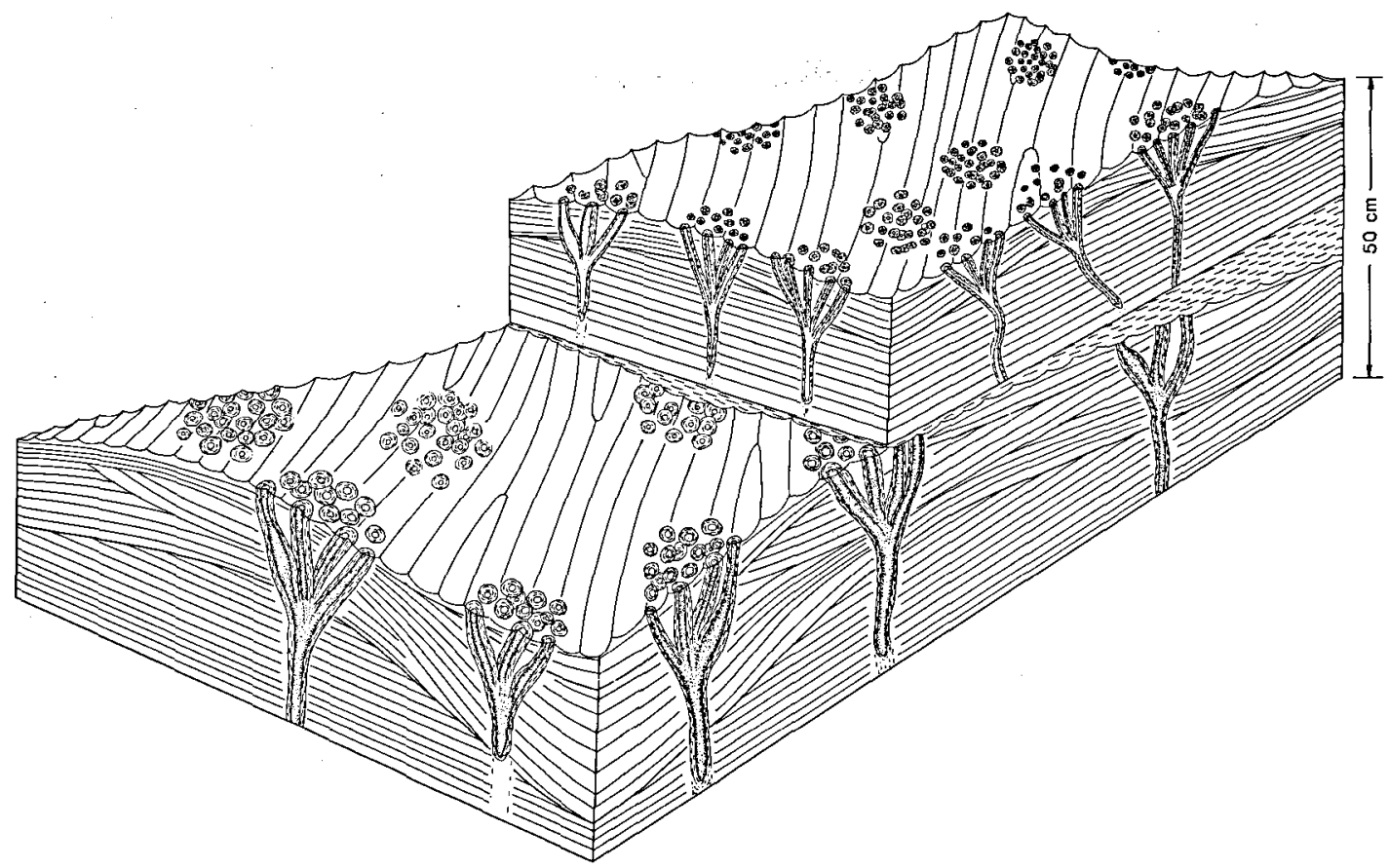

Fig. 14. Parahaentzschelinia surlyki present beneath the top of hummocky cross-stratified sandstones. Central main tunnel of each structure is classified as a fugichnion. The main structure, composed of numerous vertical tunnels, developed as the trace maker repeatedly extended itself up and outward from a central point within the sediment in search for food and is classified as a domichnion.

iation in thickness; closely associated with Phycodes bromleyi.

Discussion: The specimens are designated $P$. alternatus, in defiance of that the type species, described by Pemberton \& Frey (1982), does not include the thin mud linings present in the Neill Klinter specimens. The co-occurrence with Phycodes bromleyi suggests that the two burrows represent two different patterns of behaviour of the same organism. Ethologically, $P$. alternatus may comprise the axial domichnial from which the fodinichnial probes of $P$. bromleyi were constructed.

\section{Palaeophycus isp. (fig. 11C) MGUH 19624}

Description: Reworked fragments of straight indurated burrow fills, up to $10 \mathrm{~cm}$ Iong; burrows are cylindrical, $4-7 \mathrm{~mm}$ in diameter, and possess densely packed sand stone walls, 1-2 mm thick; burrow fill more loosely packed, passive and identical to the host rock; burrows are generally exposed in full relief.

Discussion: The indurated wall lining of the burrows may be related to substrate coherence of the host rock, probably being incohesive and loose at the time of burrowing. The thickness of the wall structure suggests that the burrows acted as permanent domiciles of infaunal organisms. However, the structures of the burrows reveal very little about the nature of the originating organism and it would not be reasonable at the present state of kowledge to attempt to identify the trace maker. The burrow is tentatively assigned to $\mathrm{Pa}$ laeophycus.

Ichnogenus Parahaentzschelinia Chamberlain, 1971

Parahaentzschelinia surlyki $\mathrm{n}$. isp.

(figs 13A, B, 14)

MGUH 19625

Holotype: The specimen illustrated in fig. $13 \mathrm{~B}$ is 
designated the holotype (MGUH 19625). The material was collected in the Gule Horn Member, Neill Klinter Formation. Top cliff section on Claudius Clavus Bjerge, east of Horsedal (approx. $1000 \mathrm{~m}$ above sea-level); $71^{\circ} 52^{\prime}, 23^{\circ} 16^{\prime}$.

Etymology: Named after Finn Surlyk, a veteran in the study of stratigraphy, sedimentology and basin evolution in East Greenland.

Diagnosis: Infaunal burrow system composed of numerous small, irregular sand filled mud lined tunnels radiating vertically or obliquely upward to sediment surface from a central, straight or slightly curved, vertically main tunnel.

Description: Vertically bundled burrows preserved in full relief or epirelief; numerous (1040) small, irregular sand filled tunnels radiating vertically or obliquely upward from a central, straight or slightly curved, vertically, sand filled main tunnel; diameter of the small tunnels are 4-20 $\mathrm{mm}$ and may vary irregularly; the central lumen are less than $4 \mathrm{~mm}$ across; burrow fills are structureless; mud linings make up a significant part of the total diameter and is up to $8 \mathrm{~mm}$ thick, lining is composed of mixed dark micaceous mudstones and fine-grained sandstones giving rise to a series of concentric rings in transverse sections; the outside of the walls may reveal scratch-like ornaments; galleries penetrate down to $50 \mathrm{~mm}$ into sandstones; surface patterns are less than 120 $\mathrm{mm}$ across; central main tunnel, $5-15 \mathrm{~mm}$ across, has an incomplete depth of $10-15 \mathrm{~cm}$; sandy burrow fill is structureless.

Discussion: $P$. surlyki differs from the type species $P$. ardelia, described by Chamberlain (1971), in its characteristic irregular well-developed wallstructure, its larger size and its vertical main tunnel. Moreover, the Neill Klinter specimen lacks the lateral gallery of $P$. Ardelia. $P$. surly $k i$ is present in very large numbers just beneath the top of fine-grained hummocky cross-statified sandstones. Owing to this setting it is suggested that the central main tunnel is classified as a fugichnion. The main structure seems to have developed as the trace maker repeatedly extended itself up and outward from a fixed point within the sediment in search for food and is classified as a domichnion. The thick wall lining of $P$. surlyki may be related to substrate coherence, which was probably incohesive and loose at the time of burrowing. The structure of the burrow reveals very little about the nature of the originating organism and it would not be reasonable at the present state of knowledge to attempt to identify the trace maker.

Ichnogenus Pelecypodichnus Seilacher 1953

Pelecypodichnus amygdaloides Seilacher 1953 (fig. 9C)

MGUH 19626

Description: Almond-shaped burrows preserved in clusters on soles of sandstone beds as hyporeliefs; the hyporeliefs measure $2-34 \mathrm{~mm}$ in length and $2-25 \mathrm{~mm}$ in width; hyporeliefs are raised above the surface by up to $17 \mathrm{~mm}$; pointed ends and longitudinal ridge-like ornaments over the deepest part are commonly present; small protuberances may extend from the ridge-like structures; the surfaces are generally smooth, but in one case, where the surface is furrowed.

Discussion: Pelecypodichnus is widely accepted as a resting trace of bivalves (cubichnia). The pointed ends and the ridge-like structure over the deepest part probably represent the valve margins (e.g. Wright \& Benton 1987) and the small protuberances are the imprints from the foot of the bivalves. The furrows of one of the surfaces probably represents the impression of ornament of a valve.

Ichnogenus Phoebichnus Bromley \& Asgaard, 1972

Phoebichnus trochoides Bromley \& Asgaard, 1972 (fig. 9A)

Description: Central shaft with an unknown depth and $5-8 \mathrm{~cm}$ in diameter with numerous long, straight burrows, up to $40 \mathrm{~cm}$ long, generally radiating horizontally from it, however, occasionally they are radiating obliquely upward to the sediment surface with an inclination less than $45^{\circ}$; radial burrows have a diameter up to $1.5 \mathrm{~cm}$ including a lumen $\mathrm{c} .1 \mathrm{~cm}$ wide containing active fill with meniscus convex towards the shaft, and a 


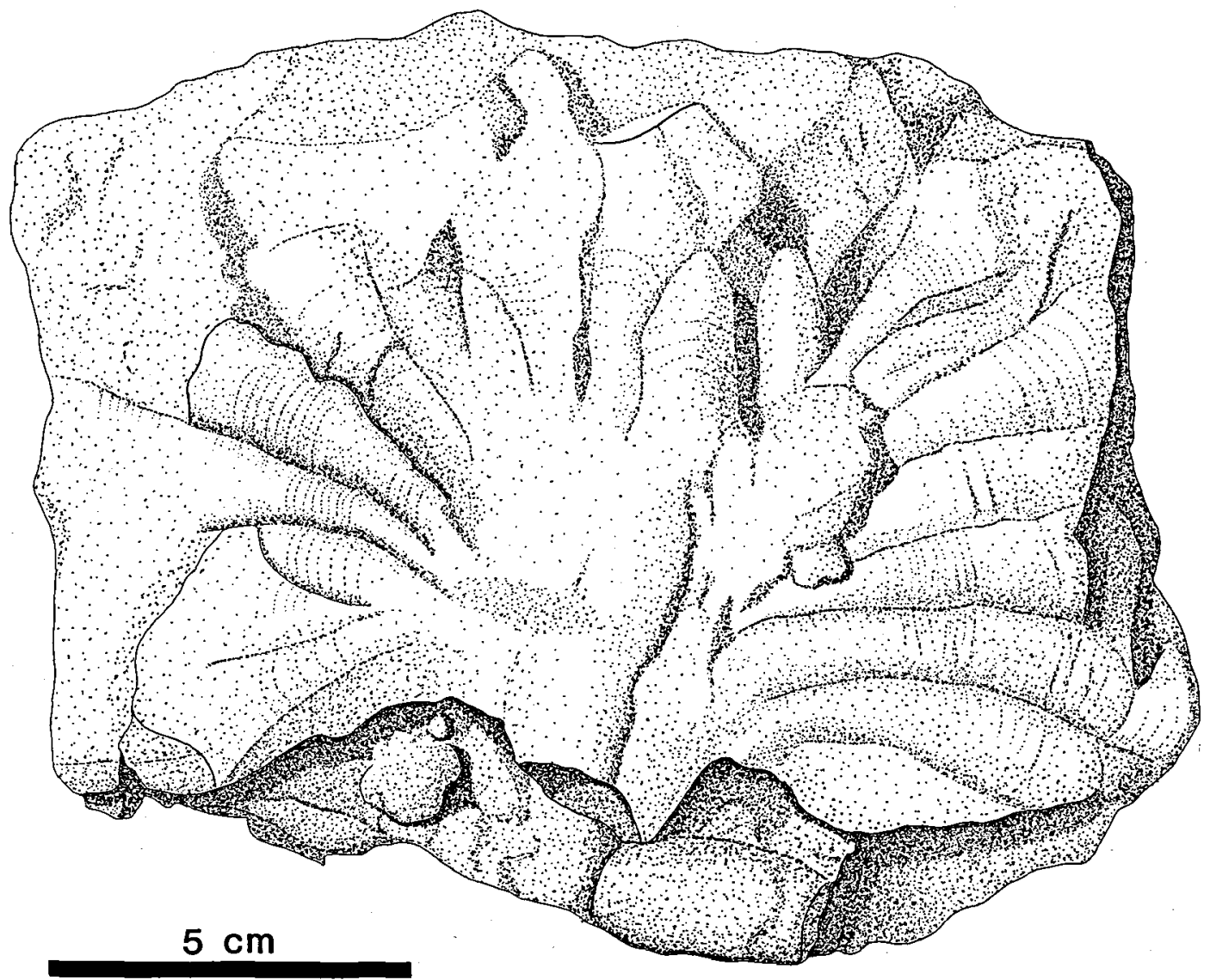

Fig. 15. Phycodes bromleyi, (MGUH 19627).

mantle $5 \mathrm{~mm}$ thick composed of discrete annuli concave towards the shaft; an annulation is imparted by the wall to the surface of the fill and the surrounding sediment; often present in large numbers in distinct horizons.

Discussion: $P$. trochoides is known from several stratigraphic levels in the Jurassic of Jameson Land (Bromley \& Asgaard 1972; Heinberg \& Birkelund 1984). It is carefully described and discussed by Bromley \& Asgaard (1972) and the present species is similar to the specimens figured by Bromley \& Asgaard (1972) and agrees with their diagnosis and interpretation. They assumed that the trace-maker lived within the central shaft and that the radial tunnels were constructed and refilled by the deposit-feeding activity of the organism (fodinichnia).

Ichnogenus Phycodes Richter, 1850
Phycodes bromleyi $\mathrm{n}$. isp. (figs 10A, 15) MGUH 19627

Holotype: The specimen illustrated in figs $10 \mathrm{~A}$ and 15 , is designated the holotype (MGUH 19627). The material was collected in the Gule Horn Member, Neill Klinter Formation. Cliff section south of Lepidopteriselv (approx. $665 \mathrm{~m}$ above sea-level); $71^{\circ} 16^{\prime} \mathrm{N}, 22^{\circ} 35^{\prime} \mathrm{E}$.

Etymology: Named after Richard G. Bromley, a veteran in ichnology and the first to introduce the auther to this trace fossil.

Diagnosis: Infaunal horizontally bundled burrows arranged in a flabellate pattern; each burrow system consists of 15-30 closely stacked short mud lined tunnels that show delicate annulations; tunnels thicken distally toward the exterior part of the burrow and divide in acute angles from a 
distinct central "radiation" point at the end of a subhorizontal main tunnel.

Description: Infaunal horizontally bundled burrows preserved as convex hyporeliefs; flabellate arrangement of 15-30 closely stacked short mud lined tunnels $(6-9 \mathrm{~cm}$ long) which divide in acute angles from a distinct central "radiation" point at the end of a subhorizontal main tunnel (Palaeophycus alternatus); individual tunnels thicken distally (from 4-6 mm to 16-18 $\mathrm{mm}$ ) and may show delicate annulations; burrow systems are seldom more than $3 \mathrm{~cm}$ deep and occur in large numbers at distinct beds; burrow systems are somewhat flattened owing to later compaction; fill is composed of fine-grained sandstone, and there is no marked lithological differences between this and the host rock.

Discussion: The ichnogenus Phycodes is very variable (Häntzschel 1975) and includes a large number of species ( $P$. circinatum Richter 1853, $P$. ?antecedens Webby 1970, P. coronatum Crimes \& Anderson 1985, P. curvipalmatum Pollard 1981, P. flabellum Miller \& Dyer 1878, Buthotrepsis palmata Hall 1852 and P. pedum Seilacher 1955). The Neill Klinter specimens most closely resemble the flabellate burrow of the type species $P$. circinnatum, but show the following main differences: 1) the branches are not parallel with the main axis before they fan out, 2) the proximal portion of the structure does not include retrusive spreiten, 3) burrows have fewer branches and are more closely spaced, 4) branches have a larger diameter that increases distally, and 5) burrows have a distinct central "radiation" point. $P$. bromleyi does not possess the radial spreiten of the flabelliform Dactyloides ottoi, described by Fürsich \& Bromley (1985). The expanding nature of the tunnels, the distinct "radiation" point and the lack of spreite all place the present form close to radiating forms (e.g. Asterophycus, Asterosoma, Stelloglyphus, Gyrophyllites). However, all of these forms are vertical burrows, with a vertical central tube from which a number of probes radiate horizontally. $P$. bromleyi is clearly different by having a horizontal main tunnel and a flabellate arrangement. As all ready pointed out, the present structure does not resemble $P$. circinnatum, although more so than some other structures called Phycodes in the litterature! It is only tentatively assigned to Phycodes because of the flabelliform arrangement. Probably a new ichnogenus should be established for flabelliform burrows with a distinct central "radiation point", including both $P$. bromleyi and $P$. auduni.

Phycodes is generally related to the systematic deposit-feeding behaviour of a stationary infaunal worm-like organism that first mined forwards and then pulled backwards, then advancing in a slightly different trajectory and so on (Seilacher 1955b; Osgood 1970; Webby 1970; Frey 1975; Bjerstedt 1988). However, the burrow system could probably have been made by any one of a number of organisms. The co-occurence with $\mathrm{Pa}$ laeophycus alternatus suggests that $P$. bromleyi comprise the fodinichnial probes that divide from the axial domichnion ( $P$. alternatus).

Phycodes auduni n. isp. (fig. 13C) MGUH 19628

Holotype: The specimen illustrated in fig. $13 \mathrm{C}$ is designated the holotype (MGUH 19628). The material was collected in the Gule Horn Member, Neill Klinter Formation. Cliff section south of Lepidopteriselv (approx. $665 \mathrm{~m}$ above sealevel); $71^{\circ} 16^{\prime} \mathrm{N}, 22^{\circ} 35^{\prime} \mathrm{E}$.

Etymology: Named after Jan Audun Rasmussen, my assistant for the 1987 field season, who helped with the sampling of a large part of the figured material.

Diagnosis: Infaunal horizontally bundled burrows arranged in a flabellate pattern; each burrow system consists of $20-40$ closely spaced tunnels which divide from a distinct central "radiation" point placed at the end of a subhorizontal main tunnel.

Description: Infaunal horizontally bundled burrow systems preserved as convex hyporelief; flabellate arrangement of 20-40 closely stacked tunnels (15-40 $\mathrm{mm}$ long) which divide from a distinct central "radiation" point placed at the end of a subhorizontal main tunnel, 6-10 $\mathrm{mm}$ across; individual tunnels is $1-3 \mathrm{~mm}$ across and rarely branch distally; burrow systems are somewhat flattened owing to later compaction; fill is composed of structureless fine-grained sandstone, and there is no marked lithological differences between this and the host rock. 
Interpretation: This species closely resemble $P$. bromleyi but is smaller in size and tunnels lack annulations, may show branching and does not expand in diameter distally. It shows the same main differences from the type species $P$. circinnatum as listed in the discussion of $P$. bromleyi. Ethologically, it resembles $P$. bromleyi.

\section{Ichnogenus Phycosiphon von Fischer-Ooster,} 1858

Phycosiphon incertum von Fischer-Ooster, 1858 (fig. 10D)

MGUH 19629

Description: Small, elongate, branched Ushaped loops, 1-2 mm wide, forming "antlershaped" systems preserved on bedding planes.

Discussion: Ethologically, Phycosiphon probably represents the systematic deposit-feeding behaviour of an infaunal organism and can be classified as a fodinichnion (Chamberlain 1971).

Ichnogenus Planolites Nicholson, 1873

Planolites beverleyensis Billings, 1862 (fig. 9E)

Description: Unlined, straight to gently curved, unbranching burrow with smooth or slightly irregular walls; circular to elliptical in cross-section, 4-15 $\mathrm{mm}$ in diameter; subparallel to bedding and preserved in full relief or convex and concave semireliefs; burrow fill composed of structureless sand.

Discussion: Planolites probably represents active backfilling of sediment in an ephemeral burrow constructed by a mobile worm-like depositfeeder (pascichnia) (Pemberton \& Frey 1982; Pemberton \& Jones 1988).

Ichnogenus Rhizocorallium Zenker, 1836

Rhizocorallium irregulare Mayer, 1954

(fig. 10B, C)

MGUH 19630

Desription: Straight to strongly curved unbranching and branching U-burrows with protusive spreiten; branching occurs in advanced forms;
5-10 $\mathrm{mm}$ in tube diameter and $18-30 \mathrm{~mm}$ width; burrows are parallel to or gently oblique to bedding; limbs more or less parallel and distinct; burrows generally have a considerable length parallel to bedding with no vertical burrows observed; ellipsoidal pills, probably faecal pellets, may be incorporated in the tubes.

Discussion: One specimen of $R$. irregulare continue into a gently oblique, trochospiral burrow which may be interpreted as $R$. uliarense Firton, 1958 , but the identification is impeded by the fact that only one half-turn of the spiral is preserved.

Fürsich (1974a) interpreted $R$. irregulare and $R$. uliarense as fodinichnia produced by depositfeeders. Crustaceans or annelids are the most probable trace-makers (Fürsich 1974a; Basan \& Scott 1979).

Ichnogenus Scolicia de Qatrefages, 1849

\section{Scolicia isp. (fig. $5 \mathrm{~F}$ ) \\ MGUH 19631}

Description: Subhorizontal trail preserved in full relief or convex epirelief with upwardly convex bilobate ridges and a flat convex downward structure beneath; trail is straight and preserved length is $25 \mathrm{~cm}$; width is $35 \mathrm{~mm}$ and thickness 15 $\mathrm{mm}$; elevated upper ridges have a steep outer wall, $3 \mathrm{~mm}$ high, and a slightly inclined inner wall that terminates in a medial furrow; in cross-section the lower part of the trail is bowl-shaped with steeply inclined straight outer walls; the lower structure is $23 \mathrm{~mm}$ wide and in the middle a dark string, $3-5 \mathrm{~mm}$ wide, is present parallel to the burrow axis; burrow fill shows bilobate backfill structures which on the outer surface are present as transverse markings arranged in a chevron-like pattern.

Discussion: The medial string is considered faecal in origin, because of its darkness compared to the surrounding sediments, indicating that the trace maker was actively feeding as it passed through the sediment. Thus it is considered as a pascichnion. Arthropods (Rodriquez \& gutschick 1970), gastropods (Miller \& Knox 1985), and irregular echinoids (Bromley \& Ekdale 1986) produce traces that have been referred to Scolicia. The median string places it close to structures pro- 
duced by echinoids today, but the geological age is too early for spatangoid echinoids. A holothurian or a large polychaete are considered as the most likely trace makers.

Ichnogenus Taenidium Heer, 1877

Taenidium serpentinum Heer, 1877 (fig. 11A) MGUH 19631

Description: Unlined or very thinly mud lined cylindrical serpentiform burrow having wellspaced meniscate backfill; distance between menisci is $1-4 \mathrm{~mm}$ and burrow width is $5-10 \mathrm{~mm}$; preserved in full relief or epirelief in fine to medium-grained micaceous sandstone; both secondary and primary successive branching and intersections seems to occur (terminology of D'Alessandro and Bromley 1987).

Discussion: $T$. serpentinum was carefully discussed and revised by D'Alessandro and Bromley (1987). The specimens from the current study are similar to the specimens from the Neill Klinter Formation figured by D'Alessandro and Bromley (1987) and the present author agrees with their amended diagnosis. Taenidium may be related to the activity of an advancing organism, probably combining the activity of deposit-feeding and locomotion (pascichnia).

Ichnogenus Teichichnus Seilacher, 1955

Teichichnus isp. (fig. 11B)

Description: Horizontal burrows with retrusive spreiten, stacked vertical to bedding; preserved in full relief; burrow diameter is $10-15 \mathrm{~mm}$, and depth of burrow is up to $5 \mathrm{~cm}$.

Discussion: Teichichnus is a burrow formed by deposit-feeders (Seilacher 1955b; Häntzschel 1975). They are generally related to burrows of annelids or arthropods (and can be classified as a fodinichnion e.g. Pickerill et al. 1984; Vossler \& Pemberton, 1989).

Ichnogenus Thalassinoides Ehrenberg, 1944 MGUH 19633

Thalassinoides isp. (fig. 11E)
Description: Horizontally or vertically branching cylindrical burrows forming two-dimensional "mazes" or three-dimensional "boxwork" systems; individual burrows show Y- and T-shaped branching and the diameter is more or less constant except at branching points and turnarounds; $3-50 \mathrm{~mm}$ in diameter; many burrows show a dark, thin wall lining covered by scratch marks; burrow fill is passive, composed of sands identical to the host rock, locally with small mudflakes, granules and crinoid fragments; burrows are preserved in full relief, hyporelief or epirelief; concretions formed within the burrow system, contain locally abundant body fossils of the shrimp Glyphea rozenkrantzi.

Discussion: The presence of Glyphea rosen$k$ rantzi in the burrow fill indicates that this crustacean was the trace maker (Bromley \& Asgaard 1972). Following reports on the diet of architects of recent Thalassinoides, the burrow is classified as a fodinichnion (cf. Fürsich 1976)

Trackways

Two individual trackways occur on rippled bedding surfaces of the Neill Klinter Formation.

Type 1 (fig. 12C)

MGUH 19634

Description: Single trackway with a width of approximately $9 \mathrm{~cm}$ preserved on a wave-rippled bedding surface as concave epirelief; consists of two parallel rows of poorly preserved imprints; the outermost imprints are composed of irregular crescent-shaped furrows, the deepest part located in the exterior part of each furrow; the innermost imprints, which are closest the midline of the trackway, have a spine-like appearance and are arranged alternately on either side of the midline, gently tapering toward the presumed direction of movement.

Discussion: The type 1 trackway has many features in common with documented arthropod trackways and is interpreted as such. However, the single occurrence and the lack of finer details precludes any closer description of the trace.

Type 2 (fig. 12D) 
Description: Morphologically a simple trackway with a width of about $5 \mathrm{~cm}$, consisting of a series of fine tracks elongated parallel to the trackway axis; individual tracks are slightly crescentshaped furrows, approximately $0.5 \mathrm{~cm}$ long, with the deepest part being located in the anterior end of the tracks.

Discussion: The trace seems very similar to modern crab trackways (cf. Frey, Curran \& Pemberton 1984, figs 2, 3a) and is tentatively interpreted as representing a sideways trackway of a crab crossing a rippled subtidal sandflat. The trace can be classified as a repichnia.

Acknowledgements. This paper is part of a $\mathrm{PhD}$-project supervised by Finn Surlyk and financed by British Petroleum Development, London. I am indepted to Finn Surlyk, Richard Bromley and Claus Heinberg for numerous discussion and critical reading of the manuscript. Thanks also to J. Audun Rasmussen, A. Boesen and $M$. Willumsen for good company in the field. Technical assistance was provided by J. Lautrup, P. Bondesen, B. Sikker Hansen, J. Halskov and V. Hermansen. The paper is published with the approval of the Geological Survey of Greenland.

\section{Dansk sammendrag}

Undersøgelser i den lavmarine nedre jurassiske Neill Klinter Formation i Østgrønland har resulteret i identifikation af 34 sporfossil arter fordelt på 29 sporfossil slægter. Beskrivelsen indeholder 4 nye former: Jamesonichnites heinbergi (n. igen., $\mathbf{n}$. isp.), Parahaentzschelinia surlyki (n. isp.)., Phycodes auduni (n. isp.) and Phycodes bromleyi (n. iso). Sporfossilerne er tolket på baggrund af de ernærings- og adfærdsmønstre de afspejler og, hvor muligt, relateret til en bestemt gruppe af organismer. Neill Klinter sporfossil selskabet er det selskab i den $\emptyset$ stgrønlandske lagserie, der udviser den største diversitet og indeholder i store træk, alle tidligere beskrevne jurasiske og nedre kretassiske sporfossiler fra denne region.

\section{References}

Alpert, S. P. 1973: Bergaueria Prantl (Cambrian and Ordovician), a probable actinian trace fossil. J. Paleont. 47, 919924.

Basan, P. B. \& Scott, R. W. 1979: Morphology of Rhizocorallium and associated traces from the Lower Cretaceous Purgatoire Formation, Colorado. Palaeogeog., Palaeoclim., Palaeoecol. 28, 5-23.

Bjerstedt, T. W. 1987: Latest Devonian - earliest Mississippian nearshore trace-fossil assemblages from West Virginia, Pennsylvania and Maryland. J. Paleont. 61, 865-889.

Bjerstedt, T. W. 1988: Trace fossils from the Early Mississippian Price Delta, southeast West Virginia. J. Paleont. 62, 506-519.

Bromley, R. G. \& Asgaard, U. 1972: Notes on Greenland trace fossils. I-III. Rapp. Grønlands geol. Unders. 49, 30 p.

Bromley, R. G. \& Asgaard, U. 1979: Triassic freshwater ichnocoenoses from Carlsberg Fjord, East Greenland. Palaeogeog., Palaeoclimat., Palaeocol. 28, 39-80.
Bromley, R. G. \& Ekdale, A. A. 1986: Composite ichnofabrics and tiering of burrows. Geol. Mag. 123, 59-65.

Chamberlain, C. K. 1971: Morphology and ethology of trace fossils from Quachita Mountains, southeastern Oklahoma. J. Paleont. 45, 212-246.

Chrisholm, J. I. 1985: Xiphosurid burrows from the Lower Coal Measures (Westphalian A) of West Yorkshire. Palaeont. $28,619-629$.

D'Alessandro, A. \& Bromley, R. G. 1987: Meniscate trace fossils and the Muenstreria-Taenidium problem. Palaeont. 30, 743-763.

D'Alessandro, A., Bromley, R. G. \& Stemmerik, L. 1987: Rutichnus: a new ichnogenus for branched, walled, meniscate trace fossils. J. Paleont. 61, 1112-1119.

Dam, G. 1989: A sedimentological analysis of the Upper Triassic to Lower Jurassic succession in Jameson Land, central East Greenland. An interim report, Part I, 26 pp; Part II, Figures and figure captions. the Geological Survey of Greenland.

Dam, G. in press: Palaeoenvironmental significance of trace fossils from the shallow marine Lower Jurassic Neill Klinter Formation, East Greenland, Palaeogeogr. Palaeo. climt., Paloeoecol.

Eager, R. M. C., Baines, J. G., Collinson, J. D., Hardy, P. G. Okolo, S. A. \& Pollard, J. E. 1985: Trace fossil assemblages and their occurrence in Silesian (Mid-Carboniferous) deltaic sediment of the central Pennine Basin, England. In Corran, H. A. (ed.): Biogenic structures: Their use in interpreting depositional environments. Soc. Econ. Paleont. Mineralog. Spec. Publ. 35, 99-149.

Frey, R. W. 1975 (ed.): The study of trace fossils. Springer Verlag, New York, 562 pp.

Frey, R. W., Curran, H. A. \& Pemberton, S. G. 1984: Tracemaking activities of crabs and their environmental significance: The ichnogenus Psilonichnus. J. Paleont. 58, 333 350.

Frey, R. W., Howard, J. D. \& Pryor, W. A. 1978: Ophiomorpha: its morphologic, taxonomic and environmental significance. Palaeogeog., Palaeoclimat., Palaeoecol. 23, 199-229.

Fürsich, F. T. 1974a: Ichnogenus Rhizocorallium. Paläontol. Z. $48,16-29$.

Fürsich, F. T. 1974b: On Diplocraterion Torell 1870 and the significance of morphological features in vertical, spreitenforming, U-shaped trace fossils. J. Palaeont. 48, 952-962.

Fürsich, F. T. 1975: Trace fossils as environmental indicators in the corallian of England and Normandy. Lethaia 8, 151172.

Fürsich, F. T. 1976: The use of macroinvertebrate associations in interpreting Corallian (Upper Jurassic) environments. Palaeogeog., Palaeoclimat., Palaeoecol. 20, 235-256.

Fürsich, F. T. \& Heinberg, C. 1983: Sedimentology, biostratinomy and palaeoecology of an Upper Jurassic offshore sand bar complex. Bull. geol. Soc. Denmark 31, 67-95.

Fürsich, F. T. \& Bromley, R. G. 1985: Behavioural interpretation of a rosetted spreite trace fossil: Dactyloides otto: (Geinitz). Lethaia 18, 199-207.

Goodwin, P. W. \& Anderson, E. J. 1974: Structures of a Cambrian tidal sand body. J. Geol. 82, 779-799.

Håkansson, E., Birkelund, T., Heinberg, C. \& Willumsen, P. 1971: Preliminary results of mapping the Upper Jurassic and Lower Cretaceous sediments of Milne Land. Rapp. Grønlands geol. Unders. 37, 32-41.

Hakes, W. G. 1977: Trace fossils in the Late Pennsylvanian cyclothems, Kansas. In Crimes, T. P. \& Harper, J. C. (eds.): Trace fossils 2. Geol. Journ. spec. Issue 9, 209-226.

Häntzschel, W. 1970: Star-like trace fossils. In Crimes, T. P. \& Harper, J. C. (eds.): Trace fossils. Geol. Joum. spec. Issue 3, 201-214.

Häntzschel, W. 1975: Trace fossils and problematica, second 
edition. In Teichert, C. (ed.): Treatise on invertebrate paleontology, Pt. W. Miscellanea, Supp. 1: Geol. Soc. Amer and Univ. Kansas, Lawrence, 1-269.

Heinberg, C. 1970: Some Jurassic trace fossils from Jameson Land (East Greenland). In Crimes, T. P. \& Harper, J. C. (eds.): Trace fossils. Geol. Journ. Spec. Issue 3, 227-234.

Heinberg, C. 1973: The internal structure of the trace fossils Gyrochorte and Curvolithos. Lethaia 6, 227-238.

Heinberg, C. 1974: A dynamic model for a meniscus filled tunnel (Ancorichnus n. ichnogen.) from the Jurassic Pecten sandstone of Milne Land, East Greenland. Rapp. Grønlands geol. Unders. 62, $20 \mathrm{p}$.

Heinberg, C. \& Birkelund, T. 1984: Trace-fossil assemblages and basin evolution of the Vardekløft Formation (Middle Jurassic, central East Greenland). J. Paleont. 58, 362-397.

Howard, J. D. \& Frey, R. W. 1984: Characteristic trace fossils in nearshore and offshore sequences, Upper Cretaceous of East-central Utah. Can. J. Earth Sci. 21, 200-219.

Mason, T. R. \& Christie, A. D. M. 1986: Palaeoenvironmental significance of ichnogenus Diplocraterion Torell from the Permian Vryheid Formation of the Karoo Supergroup, South Africa. Palaeogeogr., Palaeoclimat., Palaeoecol. 52, 249-265.

Metz, R. 1987: Sinusoidal trail by a Recent biting ridge (Family Ceratopogonidae): Trace fossil implications. J. Paleont. 61, 312-314.

Miller, M. F. \& Knox, L. W. 1985: Biogenic structures and depositional environments of a Lower Pennsylvanian coalbearing sequence, northern Comberland Plateau, Tennesee, U. S. A. In Curran, H. A. (ed.): Biogenic structures: their use in interpreting depositional environments. Soc. Econ. Paleont. Mineralog. Spec. Publ. 35.

Moussa, M. T. 1970: Nematode trails from the Green River Formation (Eocene) in the Vinta Basin, Utah. J. Paleont. 44, 304-307.

Osgood, R. G. 1970: Trace fossils of the Cincinnati area. Paleontgr. am. 6, 281-444.

Pemberton, S. G. \& Frey, R. W. 1982: Trace fossil nomenclature and the Planolites-Palaeophycus dilemma. J. Paleont. $56,843-881$.

Pemberton, S. G., Frey, R. W. \& Bromley, R. G. 1988: The ichnotaxonomy of Conostichus and other plug-shaped ichnofossils. Can. J. Earth Sci. 25, 866-892.

Pemberton, S. T. \& Jones, B. 1988: Ichnology of the Pleistocene Ironshore Formation, Grand Caymen Island, British West Indies. J. Paleont. 62, 495-505.

Pickerill, R. K., Fillion, D. \& Harland, T. L. 1984: Middle Ordovician trace fossils in carbonates of the Trenton Group between Montreal and Quebec City, St. Lawrence Lowland, eastern Canada. J. Paleont. 58, 416-439.

Rodriguez, J. \& Gutschick, R. C. 1970: Late Devonian - Early Mississippian ichnofossils from western Montana and northern Utah, In Crimes, T. P. \& Harper, J. C. (eds.): Trace fossils. Geol. Journ. Spec. Issue 3, 407-438.

Rosenkrantz, A. 1929: Preliminary account of the geology of Scoresby Sund district, p. 133-154. In Koch, L. (ed.): The geology of East Greenland. Meddr Grønland 73, 135-154.

Rosenkrantz, A. 1934: The Lower Jurassic rocks of East Greenland. Pt. I. Meddr Grønland 119 (1), 122 pp.
Seilacher, A. 1953: Studien zur Palichnologie II. Die Fossilen Ruhespuren (Cubichnia). Neues Jahrb. Geol. Paläontol. 98, 87-124.

Seilacher, A. 1955a: Spuren und Lebensweise der Trilobiten. In Schindewolf, O. H. \& Seilacher, A. (eds.): Beitrage zur kenntnis des Kambriums in der Salt Range (Pakistan). Akad. Wiss. Lit. Maintz, math.-nat. kl., Abhandl. 10, 86-116.

Seilacher, A. 1955b.: Spuren und Fazies im Unterkambrium. In Schindewolf, O. H. \& Seilacher, A. (eds.): Beitrage zur kenntnis des Kambriums in der Salt Range (Pakistan). Akad. Wiss. Lit. Maintz, math.-nat. kl., Abhandl. 10, 117-143.

Seilacher, A. 1960: Lebensspuren als Leitfossilien. Geolog. Rundschau 49, 41-50.

Seilacher, A. 1977: Pattern analysis of Paleodictyon and related trace fossils. In Crimes, T. P. \& Harper, J. C. (eds.) Trace Fossils. Geol. Journ. Spec. Issue 9, 289-334.

Seilacher, A. \& Meischner, D. 1964: Fazies-analyse im Paläozoikum des Oslo-gebietes. Geolog. Rundschau 54, 596619.

Surlyk, F., Callomon, J. H., Bromley, R. G. \& Birkelund, T. 1973: Stratigraphy of the Jurassic - Lower Cretaceous sediments of Jameson Land and Scoresby Land, East Greenland. Bull. Grønlands geol. Unders. 105 (also Meddr Grønland $193(5)$ ), $76 \mathrm{pp}$.

Surlyk, F. \& Clemmensen, 1. 1983: Rift progradation and eustacy as controlling factors during the Jurassic inshore and shelf sedimentation in Northern East Greenland. Sediment. geol. 34, 119-143.

Surlyk, F., Clemmensen, L. \& Larsen, H. C. 1981: Post-Paleozoic evolution of the East Greenland continental margin. In Kerr, J. W. \& Ferguson, A. J. (eds.): Geology of the North Atlantic Borderlands. Mem. Can. Soc. Petrol. 7, 611-645.

Surlyk, F. \& Noe-Nygaard 1989: Shelf sand banks and sand dune fields from the Volgian-Valanginian Raukelv Formation of Jameson Land. Rapp. Gronlands geol. Unders. 145, 74-75.

Sykes, R. M. 1974a: Sedimentological studies in southern Jameson Land, East Greenland. I. Fluviatile sequences in the Kap Stewart Formation (Rhaetic-Hettangian). Bull. geol. Soc. Denmark-23, 203-212.

Sykes, R. M. 1974b: Sedimentological studies in southern Jameson Land, East Greenland. II. Offshore-eustarine regressive sequences in the Neill Klinter Formation (Pliensbachian-Toarcian). Bull. geol. Soc. Denmark 23, 213-224.

Vossler, S. M. \& Pemberton, S. G. 1989: Ichnology and palaeoecology of offshore siliciclastic deposits in the Cardium Formation (Turnion, Alberta, Canada). Palaeogeog., $\mathrm{Pa}$ laeoclimat., Palaeoecol. 74, 217-239.

Webby, B. D. 1970: Late Precambrian trace fossils from New South Wales. Lethaia 3, 79-109.

Wright, A. D. \& Benton, M. J. 1987: Trace fossils from Rhaetic shore-face deposits of Staffordshire. Palaeont. 30, 407428. 